Preliminary, Please do not quote

November 2009

\title{
Board Interlocks and Earnings Management Contagion
}

\author{
Peng-Chia Chiu \\ Merage School of Business, UC-Irvine \\ Siew Hong Teoh* \\ Merage School of Business, UC-Irvine \\ Feng Tian \\ School of Business, The University of Hong Kong
}

We examine whether earnings management spreads from firm to firm via board connections. We find that contagion of accounting quality occurs via directors in interlocking boards with other firms. A firm with director links to firms that restated earnings tends to have poorer accounting quality and higher likelihood of restating its own financial reports. A firm with director links to firms that did not restate earnings tends to have higher accounting quality. This evidence supports the idea that economic behavior such as accruals management spreads through social networks.

*Corresponding author 


\title{
Board interlocks and earnings management contagion
}

\author{
By Peng-Chia Chiu, Siew Hong Teoh, Feng Tian
}

"Hee that lies with the dogs, riseth with fleas."

- Outlandish Proverbs No. 343

\section{Introduction}

Theoretical research on social influence has examined how information and behaviors are propagated from individual to individual (e.g., Banerjee 1992;

Bikhchandani et al. 1992). A growing body of research on social networks examines how social linkages affect the spread of behaviors and social outcomes.

Behaviors can spread for several reasons. Rational observers may follow the behavior of others based on either direct communication of the rationale for the chosen action, or through observation of the action. In either case, rational Bayesian updating can lead to similar behavior. Observers may also imitate because of a preference to conform, or because of excessive deference to the judgment of a high-prestige model.

On the empirical side, recent research has documented that several types of corporate behaviors such as compensation practices, poison pill adoption, and stock exchange listing decisions spread through networks of interlocking boards (see Hirshleifer and Teoh 2003, 2009; Bizjak et al. 2009; Rao et al. 2000; Davis 1991etc. ). Hirshleifer and Teoh (2009) speculate that financial reporting practices (earnings management included) are also likely to be infectious in social networks. Srinivasan (2005) provide evidence that a restatement of earnings by one member firm in a network of firms with interlocking boards contaminates the stock values of other firms in the network. 
In this paper we test empirically whether financial reporting behaviors, specifically earnings management, are propagated through interlocking boards. To do so, we examine the effects on firm behavior of sharing a director with another firm that was involved with a financial restatement. We find that a firm has incrementally lower quality earnings (measured variously as higher accruals quality or absolute value of discretionary accruals) and a greater likelihood of restating its own financial statements if it has a board member that also sits on the board of another firm that restated its financial statements than otherwise. This contagion occurs regardless of whether the restatement-linked firms are in the same industry or not. If that board member is an inside director of the contaminated (i.e., restatement-linked) firm, the contagion is even stronger. On the other hand, firms that are board-linked to high quality earnings firms also have higher quality earnings. These findings are robust to various sensitivity checks.

These results contribute to the accounting and social network literature by demonstrating that earnings management behavior propagates from one firm to another through board interlocks. The majority of most previous studies on earnings management treat earnings management behavior as a firm-specific behavior, while Granovetter (1985) suggests that economic actions are embedded in social networks such as board interlocks. Therefore, our study expands earnings management research into social network settings. Our paper is also related to the accounting literature on the influence of geography on accounting behavior (e.g., Kedia and Rajgopal 2008a; Defond et al. 2009). The key difference is that we consider board interlocked members as a specific conduit for behavior propagation in the network instead of geographic proximity to facilitate contagion. Furthermore, our paper also contributes to the corporate governance literature 
by evaluating whether firm monitoring is influenced by social networks within interlocked boards. Our findings suggest that to improve financial reporting quality, regulators also need to pay attention to the board connectivity of companies.

The remainder of the paper is organized as follows. Section II summarizes related research and discusses our predictions on how board links to restating firms affect earnings quality and the propensity of earnings management. Second III discusses the research design and the sample. Section IV presents our results and Section V concludes our paper.

\section{Prior research and background}

We use restatements to identify previous earnings management because restatements are clear indicators of GAAP violations (Palmrose and Scholz 2004); other earnings management proxies such as discretionary accruals are statistical measures and remain controversial in the literature. Previous studies show that the disclosures of earnings restatement are related to large market value losses. For example, Palmrose, Richardson, and Scholz (2004) report a $-9.2 \%$ of market return loss over a two-day $(0,1)$ of restatement announcement period, and Hribar and Jenkins (2004) find that the cost of capital rises after restatements. Moreover, Gleason et al. (2008) explore the industry contagion effect of earning restatements from the investor's perspective, and find that when a firm restates, the peer firms in the same industry also experience stock price declines.

Existing studies on earnings management treat earnings management from a firm specific perspective (e.g., Healy 1985; Jones 1991). However, corporate behaviors are 
embedded in social networks, and executives' corporate decisions are largely influenced by other companies through these social network ties such as board interlocks (Granovetter 1985). Several studies have provided evidence that firm's investment, financing or financial reporting decisions can be significantly affected by other companies through social networks (as reviewed in Hirshleifer and Teoh $(2009,2003)$ ).

Kedia and Rajgopal (2008a) find some evidence that neighboring firms’ accounting practices increases a firm's tendency to misreport financial restatements. They also document that a firm's distance to the SEC offices is negatively associated with the likelihood of misreporting. DeFond et al. (2009) find that the geography of SEC enforcement is a key factor influencing auditor independence. Specifically, non-Big 4 auditors are less likely is issue going concern audit opinions when the auditor's engagement office is located farther away from the SEC offices, while Big 4 auditors have the opposite tendency. According to Kedia and Rajgopal (2008a), firms located farther away from the SEC enforcement office are more likely to misreport and Defond's result suggests that Big 4 auditors, with reputations to protect, do indeed call on the misreporting. Kedia and Rajgopal (2008b) report that the stock option granting practices of a firm are largely shaped by neighboring companies’ practices, possibly in response to competitive pressure from a local labor market where the individuals in the social network share information about compensation practices.

Previous studies document that various corporate behaviors spread through director interlocks. Davis (1991) finds that a company is more likely to adopt poison pills, one of the important anti-takeover methods, if the company is linked to the companies that have adopted poison pills through board interlocks. Haunschild (1993) documents, 
by analyzing firms in four industries during the 1980s, that companies linked to acquisitive companies tend to imitate the corporate acquisition activities of these acquisitive companies. Rao et al. (2000) find that the choice of being listed on the New York Stock Exchange or the NASDAQ is significantly affected by board interlocks. Specifically, firms listed on the NASDAQ in 1996 were more likely to migrate to the NYSE later on when their directors served on the boards of prior migrating companies, and this migrating effect was mitigated by board links to NASDAQ companies and strengthened by board links to NYSE companies. In the accounting literature, there is evidence of a labor market effect working through interlocking board networks. Srinivasan (2005) documents that the outside directors of restating firms are more likely to lose not just their board position in the restating firm but also their board positions in other firms. Thus, directors associated with problem firms suffer a reputation penalty.

Among publicly traded companies, boards of directors supervise and monitor the operation of the companies, and approve important management decisions. Board directors in America commonly sit on more than one board, and each board meets several times a year sometimes frequently as in the case of Citibank where the board met 16 times in 2002. These interlocking boards form a social network in which board members can carry knowledge and corporate practices (good or bad) from one company to another. Directors of interlocking boards, therefore, are much like agents carrying infectious viruses from one firm to another.

Within the psychology literature, there is evidence of contagion of unethical behaviors (Gino, Ayal, and Ariely. 2009). Sah (1991) points out that exposure to the dishonesty of others could lead managers to change their subjective estimate of 
manipulation costs and benefits. There is evidence that having board members who are interlocked to a backdating company increases the chance that the firm also backdates employee stock options (Bizjak et al. 2009). Fich and Shivdasani (2007) find that firms are more likely to face a financial lawsuit if they have a board member who sits on the board of another firm that has previously been sued for fraud.

Earnings management in firms is unlikely to publicize widely for obvious reasons. However, it is possible that this behavior diffuses quietly from one firm to another through board interlocks. Whether or not a company manages its earnings depends on the subjective perceived cost and benefit of such management. For example, when a company manipulates its earnings, directors linked to the manipulating firm observe such behavior through board interlocks are likely to estimate a lower perceived cost of manipulation and a higher perceived benefit. This can lead to rational herd behavior or information cascades.

Furthermore, board connections to firms that manage earnings can change the directors and managers' view of whether managing earnings is a social norm, and therefore can affect the preferences of directors and executives. The use of earnings management at other firms can be viewed as a moral justification for its use by others. In sum, direct communication of information signals, observation of actions and preference interactions through social networks (e.g., board interlocks) can all cause behaviors such as earnings management to spread from one firm to another.

Overall, based on the discussion above, we hypothesize that if a director, who is also a board member of the firm that previously managed earnings, sits on the board of a 
company, then the likelihood of earnings management for this company is greater. We discuss the research design to test this hypothesis next.

\section{Research design and data}

To examine whether there are contagion effects in accounting reporting choices amongst board-linked firms, we exploit a restatement sample because restating firms have clearly violated generally accepted accounting principles (GAAP) in the period leading up to the restatement date. We consider such firms as infectious agents for poor accounting quality. We test whether the firms that are linked via common board members with the infectious firms also have poor accounting quality.

Ideally, we would track a restatement back in time to the initial period when the accounting rules were violated. In this earliest year when the bad accounting practice is potentially infectious, we would check the names of its board of directors against the board interlock database to select the sample of firms that are exposed to the bad accounting virus for that year. We would then test the accounting quality of the exposed firms for signs of infection. This sample selection method, however, is difficult to implement because the earliest period of the bad accounting practice resulting in a restatement is not readily available. There are also multiple possible connections of restatements to firms which would make it difficult to figure out the initial period of possible contagion.

As a feasible alternative, we use the following method to select a sample of restatement-linked firms via board interlocks and to estimate the contagion period. In a given year, we begin by identifying board linkages using information about board interlocks from Risk Metrics (formerly the IRRC database). Following the board 
members of these firms to the other firms where they also sit as directors, we check whether any of these board-interlocked network firms had to restate their financial reports anytime in the prior seven years. We use the General Accounting/Government Accountability Office (GAO) database to identify whether a firm restated their financial reports. If there was a restatement, the firm is deemed restatement-linked and we test the accounting quality of the restatement-linked firm in the prior seven years when the bad accounting was contagious. ${ }^{1}$

Figure 1: Time line to illustrate the contagion period

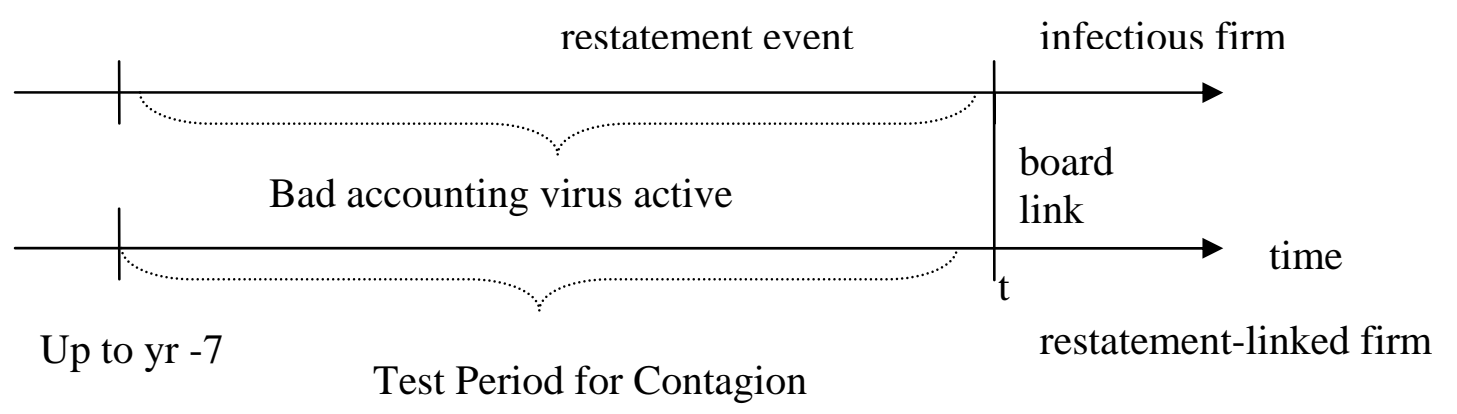

The restatements database begins in 1997. We choose 2002 as the end of our sample period to avoid potential contaminating effects because of the passage of the Sarbanes-Oxley Act (SOX) in 2002, whose goal was to improve corporate governance, particularly in board structure, of American companies.

For robustness checks, we consider the following sample selection alternatives. We extend the restatements period up to 2006, which is the post-SOX era. The time

\footnotetext{
${ }^{1}$ Figure 1 shows that the contagion period is contemporaneous with the prior seven years over which a restatement in the infectious firm occurred. Thus, the contagion period possibly includes some postrestatenent years when the reporting improved for the restating firm. Therefore, the contagion period may include a bad reporting contagion pre-restatement as well as good reporting post-restatement contagion for the test firm. In this regard, our research design is conservative for picking up negative contagion effects from the restatement firm.
} 
periods for past restatement infection varies from three to five years and the contagious period for the restatement-linked firm correspondingly varies between three and five years. We also limit restatements to just those that are identified as irregularities (intentional misstatements) by Hennes, Leone and Miller (2008).

The accounting and stock return data are from COMPUSTAT and CRSP respectively. We also use Risk Metrics and Thomson Financial databases to construct an anti-takeover variable and an institutional holding variable, both of which are likely to be related to board governance.

The contagion hypothesis is tested using a cross-sectional regression of a measure of accounting quality of the test firm on the presence of a board link to a restatement firm and other control variables. We use three different measures of accounting quality of the restatement-linked test firms (described in detail in the appendices). Follow prior literature on accounting quality, we use $A Q$, the standard deviation of the residuals in the regression of working capital accruals on cash flows in the contemporaneous period, at one lag period, and at one lead period (Dechow and Dichev 2002; McNichols 2002;

Krishnan et al. 2008.) As additional accounting quality measures, we also consider $|\overline{D A}|$, the average absolute discretionary accruals in the prior seven years and whether the restatement-linked firm itself subsequently also restated its financial reports.

To calculate our key test variable, we measure the link between the test firm and the restatement firm via a common board member in two ways. First, we consider a binary variable for the presence or absence of a board member link between the test firm and a restatement firm that restated financial reports in the past seven years, Restatelink_0/1. Just as in epidemiological cases, there is a higher rate of infection if a person is 
exposed to a greater number of infected people. Therefore, as a second measure, we count the number of board interlocks in the test firm with firms that restated their financial reports, \#Restate_link. We use the natural logarithm measure, Log(\#Restate_link) $=\log (1+$ \#Restate_link $)$ to reduce any potential extreme value effect on the overall regression. We count board interlocks in two ways. First is the number of distinct directors who are also on boards of firms that restate earnings. The other is the number of distinct restating firms with board members who are also the firm's board members. If there is one director who sits on the boards of two other firms that restated earnings, the first measure will count as one link but the second measure will count as two links. If there are two board members who also sit on the same board of another firm that restated earnings, the first measure will count as two links and the second measure will count as one link.

Since some boards are very large and so are more likely to have board interlocks, we also include a measure of the intensity of board links with other firms, \#Board-link, regardless of whether the linked firm has a restatement or not. The variable is measured as $\log (\#$ Board_link $)=\log (1+\#$ Board_link $)$. This measure will also pick up contagion effects via board members. In contrast to the restatement link situation where the contaminant is poor accounting quality, the contaminant now is the relatively good accounting quality.

Turning next to the set of control variables, we control for various measures that prior literature has found to be associated with accounting quality (e.g., Dechow and Dichev 2002; Hribar and Nichols 2007; Francis et al. 2005; Krishnan et al. 2008). We control for firm performance with return on total assets $R O A$, and the frequency of losses 
in the past seven years \#Loss. Size control variables include $\log (T A)$, the natural logarithm of total assets, and $\log (S A L E S)$, the natural logarithm of sales. Growth effects are controlled using $M B$, the market-to-book ratio. The variable Leverage is measured as the ratio total liabilities to total assets. Firm reporting quality is affected by the length of the operating cycle, measured as the sum of the number of days that accounts receivables and inventories are held. We use 360 days divided by the relevant turnover ratios to measure days held, and the natural log of the operating cycle $\log ($ Operating_Cycle $)$ as the control variable.

Since firms facing higher operating risks and likelihood of failure have greater incentives to manage earnings, we control for these variables to isolate the specific effect of board contagion that is incremental to these firm characteristics that might result in poor accounting quality. We proxy for operating risk of the firm using $\sigma_{-} C F O$ and $\sigma \_R E V$, which are measured as the standard deviation of the cash flows from operations or revenues respectively in the past five years deflated by total assets. Following Dechow et al. (2009), we also include the likelihood of restatement by the test firm that is estimated using only from financial information characteristics of the firm and averaged over the past five years. We refer to this as the $R \_$score. (See Appendix D for details.) Firms in some industries face greater costs if found to have managed earnings and we control for these using indicator variables for regulated industries and for industries that face higher litigation (Matsumoto 2002; Kasznik and Lev 1995); see Appendix A for details.

To control for other governance-related variables that may separately affect accounting quality, we include a binary variable for whether the firm is audited by a high 
quality auditor Big_Auditor, which takes on value 1 if the company is audited by either a Big 4 (or 5 or 6) auditors, and 0 otherwise. We also include a corporate governance score (Gompers et al. (2003) $\log ($ G-score) and the fraction of institutional holdings Inst_Holding .

To isolate solely the effect of contagion from board members from restatement firms as conservatively as possible, we also control for other board characteristics that prior literature has suggested is a proxy for the strength of monitoring by board. These include $C E O \_$Chair $=1$, if the CEO is also the chairman of the board, and 0 otherwise, the size of the corporate board Board_Size and the percentage of independent board members Board_Indep.

We run the following cross-sectional regressions:

$A Q \quad$ or $\quad|\overline{D A}| \quad$ or $\quad$ Restate_0/1

$=\beta_{0}+\beta_{1} \log (\# \operatorname{Re}$ state_link $)+\beta_{2} \log (\#$ Board_link $)+\beta_{3} R O A+\beta_{4} \#$ Loss

$+\beta_{5} \log (T A)+\beta_{6} \log (S A L E S)+\beta_{7} M B+\beta_{8}$ Leverage $+\beta_{9} \log ($ Operating _Cycle $)$

$+\beta_{10} \sigma_{-} C F O+\beta_{11} \sigma_{-} R E V+\beta_{12} R_{-}$score

$+\beta_{13}$ Big _ Auditor $+\beta_{14} \log (G-$ score $)+\beta_{15}$ Inst _ Holding

$+\beta_{16}$ Re gulation $+\beta_{17}$ Litigation

$+\beta_{18} C E O_{-}$Chair $+\beta_{19}$ Board _ Size $+\beta_{20}$ Board _ Indep $+\varepsilon$

When the dependent variable is Restate_0/1, a logistic regression is run and the probability of a restatement by the test firm is calculated as $F\left(\beta^{\prime} X\right)=\frac{e^{\beta^{\prime} X}}{1+e^{\beta^{\prime} X}}$. Our main variable of interest is Log(\#Restate_link). If contagion via board memberships exists, we predict that the estimated coefficient for this variable will be positive; that is, firms with board members that are linked to restatement firms have lower accounting quality (higher 
$A Q$, higher average absolute discretionary accruals, and a higher likelihood of subsequently restating its own financial statements).

In addition to the main test variable, the estimated coefficient on the variable Log (\#Board_link) carries as an interesting implication that is also new to the literature. It picks up the effect of contagion effects on accounting quality from board interlocked firms that did not restate their earnings. Relative to restatement firms, these firms are likely to have higher accounting quality, so a significant negative coefficient (lower $A Q$ proxies for higher accounting quality) would imply that contagion can also trigger positive imitations of financial reporting practices.

\section{Empirical Results}

\subsection{Summary Statistics and correlations}

Table 1 Panel A presents the summary statistics for the variables used in our analysis. The results show that the statistics for the accounting quality $A Q$ and average absolute value of discretionary accruals are comparable to other studies (e.g., Francis et al. 2005). On average, each firm observation in our sample, which covers S\&P 1500 firms, has 6.54 distinct board members who are also board members of other firms. If board interlocks as counted as the number of distinct other companies with common board members as the firm, the average number of links is 5.82 . The median number of links is 4 for both measures of board interlocks.

Restatements are relatively infrequent in the population, so when the board links are restricted to only restating firms, the mean and median numbers are drastically reduced. The mean number of links is to 0.4 and the median is actually zero. Even at the 
$75^{\text {th }}$ percentile, there is only one director linked to a restatement firm. Given the difference between the mean and median numbers, the variable is likely skewed. Therefore, the log measure may be more appropriate than the continuous measure of the variable to use in the cross-sectional regression.

With regards to correlations reported in Panel B, $R \_$score is highly correlated with both cash flow volatility $\left(\sigma_{-} C F O\right)$ and revenue volatility $\left(\sigma_{-} R E V\right)$ (0.458 and 0.485 respectively). Therefore, the coefficients of these variables should be interpreted with care, and should be considered jointly rather than separately. (For robustness, we also include these variables singly and then jointly in the regressions.) ${ }^{2}$

\subsection{Board interlocks and earnings quality}

The results for the cross-sectional regressions of accounting quality measure $A Q$ on contagion measures are reported in Table 2. In column (1), the coefficient on Log(\#Board_link) is -0.003 and highly statistically significant, implying that overall board interlocks have a positive influence on accounting quality. When the board members are linked to other restatement firms however the opposite is observed. The coefficient on Log(\#Restate_link) in Column (2) is 0.002, which is significantly positive at less than $1 \%$ level. Thus, when a firm's board is linked to firms with poor accounting quality, the company's accounting quality becomes contaminated as well. Column (3) regression includes both $\log$ (\#Board_link) and Log(\#Restate_link), and the results reveal that the relations between board interlocks and accounting quality in columns (1) and (2) separately are robust to inclusion of both variables.

\footnotetext{
${ }^{2}$ For the brevity of the paper, these regression results are provided upon request.
} 
The regression in column (4) further controls for an extensive set of firm characteristics and corporate governance variables. The board interlock variable to restating firms remains robust, but not the board interlock variable to the non-restating firms. These results are shown to be robust in the column (5) regression where the restatement board-link variable is binary instead of the log measure in column (4). Together, this evidence suggests that among the governance variables, the firm-specific board characteristics generally are more important in determining accounting quality independent of whether its board members are linked to other boards unless the association is to a restating firm. In this case, a board linkage to a restating firm results in contamination of the accounting quality from the restating firm.

In Table 3, we report the results for the regression of accounting quality measured as the absolute discretionary accruals on board interlock. All of the key results of Table 2 are shown to be robust, except that the board-linked variable to non-restating firms is also significant when both board interlock variables and other board characteristics are included in the regression. These results are highly statistically significant (less than $1 \%$ p-values) and they suggest strong support for the presence of contagion - firms where the board members are linked to poor accounting quality (restating) firms have more accruals management whereas firms where the board members are linked to good accounting quality (non-restating) firms seem to be deterred from accruals management. Comparing the size of the coefficient of $\log (\#$ Restate_link) is much larger than the coefficient for Log(\#Board_link) suggesting that negative contagion effects may be stronger than positive contagion effects. 
In Table 4, we investigate the association between future restatements and board interlocks. If the firm subsequently had to restate their financial statements, the accounting quality in the period prior to the restatement is clearly poor. By isolating only the most extreme cases in that only financial reporting that ultimately resulted in GAAP violations as poor accounting quality, the regression is a more conservative test for contagion effects. The contagion effects are strongly significant. A firm with boards linked to restating firms experiences a much greater likelihood of ultimately restating itself. On the other hand, a firm with boards linked to non-restating firms has a lower likelihood of ultimately restating. For economic significance, the estimated coefficient in column (5) suggests that the incremental probability of own firm future restatement from the mere presence of having a board link to other restating firms is $2.24 \%$. For benchmark comparison, the unconditional probability of a restatement is $3.44 \%$. Therefore, the presence of a restatement-link alone explains $65.23 \%(2.24 / 3.44=65.23 \%)$ of the unconditional likelihood of a restatement.

In sum, the evidence in Tables 2 through 4 supports a consistent message that board contagion effects are present. When the board link is to poor accounting quality firms, the firm also has poor accounting quality and when the board link is to a good accounting quality firm, the firm also has good accounting quality.

\subsection{Robustness Checks}

We conduct several further robustness tests for the contagion effects reported above. In Table 5, we limit the restatement link only to firms where the restatements were the result of irregularities using the variable Log(\#Irregular_link). These restatements are 
cleaner examples of earnings manipulation than mere errors. Both the positive and negative contagion results for board interlocks are robust for all three regressions using different accounting quality measures for the dependent variable. In column (3) regression, the dependent variable is the binary indicator of whether the firm itself subsequently restated for reasons of irregularities.

In Table 6, we measure board interlocks by counting the number of links to distinct restating companies regardless of the number of common board members shared by the common firms. The conclusions are unchanged.

The main analysis determines the existence of infectious links (i.e., restate_link) by investigating whether board members sat on any firm that restated financial reports in the past 7 years. This implies that infectious agents affect board interlocked firms for a considerable time. Therefore, we also consider a shorter history ( 3 years or 5 years) of infectiousness. The results are robust for the shorter periods, and are not tabulated for brevity.

Table 4 shows that a firm with board interlocks to other restating companies has an increased propensity to restate its own financial statements down the road. Prior studies show that firms that subsequently restated earnings have higher discretionary accruals and poorer earnings quality in the periods leading up to the restatement (e.g., Richardson et al. 2002). Therefore skeptics might consider the results in Table 2 and 3 as not entirely independent of the results in Table 4 . To check whether board contagion also exists for firms that did not ultimately restate its earnings, we eliminate these firms and rerun the tests in Tables 2 and 3. Again, the results are robust (untabulated). 
Finally, we investigate whether these results are period specific or extend to the period subsequent to the passage of the Sarbanes-Oxley Act of 2002 when board structures may have changed significantly. Extending our analysis to 2006, however, did not change the results (untabulated). Therefore, our results do not appear to be timeperiod sensitive.

\subsection{Additional Analyses}

We conduct several additional analyses to further our understanding of how board interlocks affect the diffusion of accounting practice. As a member of the management team, an inside director can be expected to have a greater influence on his fellow management colleagues and the operations of his company. Therefore, we expect that an inside director to be more likely to infect his firm with either good or bad accounting practice from the other firms where he is also a board member.

We separate the \#Restate_link related variables into two variables, one where the board member is an inside director \#Restate_Insider_link and the other where he is not. For both the $A Q$ and the probability of an ultimate restatement by own firm in column (1) and column (3) respectively of Table 7, the previous results are robust. Of interest here is that the new variable \#Restate_Insider_link is also statistically significantly positive. When accounting quality is measured using absolute discretionary accruals in column (2), the results are similar but the statistical significance is weaker for the new insider variable. Overall, the results imply that an insider director link to other restating firms strengthens the infection. 
Firms in similar industries tend to have similar accounting practices and face common business conditions. The contamination that we document may be the result of these common factors. However, one should not rule out contagion as a contributory factor if contamination effects on accounting quality are seen in board links to firms in similar industries. Firms in the same industry are competitors, and one firm's advantage from earnings management redounds to another firm's disadvantage. ${ }^{3}$ In addition, there is a concern for relative performance, as discussed by Hirshleifer and Teoh (2009), that may create a strong incentive for a firm to manage earnings when directors observe that the same industry peer firms are manipulating earnings.

These effects together suggest that same industry contagion could indeed be stronger than cross-industry contagion. To test this, we separate the restatement link variable into a same industry (based on 2-digit SIC code) link variable versus a crossindustry link variable. The results reported in columns (1) and (2) of Table 8 indeed support this contention. Directors linked to the same industry restating firms are associated with lower earnings quality. We test the coefficient differences for Log(\#Restate_link_same_ind) and Log(\#Restate_link_diff_ind) in columns (1) and (2) and find that the coefficients of $\log (\#$ Restate_link_same_ind) are significantly larger than that of Log(\#Restate_link_diff_ind) at the one percent level. The positive contagion effect from links to firms without restatements remains the same. The result for column (3) using the firm's own restatement as the dependent variable seems contrary to the above results. This may be because when a restating firm is required to restate, the

\footnotetext{
${ }^{3}$ For instance, if a company is better financed with much more cash at a lower cost of capital than its competitor, it can afford expensive R\&D investment and may dominate the market later on.
} 
restatement-linked firm in the same industry may be put on notice to fix its accounting to avert having to restate itself.

\section{Conclusions}

This paper studies the role of board interlocks in the propagation of corporate practices, specifically financial reporting, by documenting that board interlocks to restating firms reduce the earnings quality of a company and increase the likelihood of the company to restate its financial reports. We provide evidence supportive of Granovetter (1985)’s argument that economic actions are influenced by social networks

and contacts. More broadly, our findings suggest that social influence is important for financial accounting practices.

Although our focus is on a particular type of social network, board interlocks, other types of social networks may be important for financial reporting and business decisions, such as social clubs for executives (e.g. golf clubs, or country clubs, and school ties). Future studies might investigate the various types of social networks’ influence on financial reporting practices.

Our sample (which draws from the IRRC database) mainly focuses on the S\&P 1500 companies. Earnings management contagion through boards of directors in small companies and private firms are not considered. Social contacts may be even more important in small businesses and private firms, so further empirical study of social contagion across such firms is called for. 


\section{Appendix A: Variable Definitions}

$\mathrm{AQ}=$ Accruals quality based on previous studies (Dechow and Dichev 2002; McNichols 2002; Krishnan et al. 2008). See Appendix D for details;

$|\overline{D A}|=$ Average absolute value of discretionary accruals (performance-matched) over the past seven years; See Appendix C for details;

\#Restate_link $=$ Number of board directors linked to firms that have previously restated financial reports;

$\log (\#$ Restate_link $)=\log (1+\#$ Restate_link $)$; The natural logarithm of one plus Restate_link;

Restate-link_0/1=1, \#Restate_link is greater than zero, and 0 otherwise;

\#Restate_link01=Number of previously restating firms linked to the company;

$\log (\#$ Restate_link01) $=\log (1+\#$ Restate_link01); The natural logarithm of one plus Restate_link01;

\#Irregular_link=Number of board directors linked to firms that have previously been found with accounting irregularities;

Log $\left(\# I r r e g u l a r \_l i n k\right)=\log \left(1+\# I r r e g u l a r \_l i n k\right) ;$ The natural logarithm of one plus \#Irregular_link;

\#Restate_Insider_link=Number of board insider directors linked to firms that have previously restated financial reports;

Log(\#Restate_Insider_link $)=\log (1+\#$ Restate_Insider_link $)$; The natural logarithm of one plus \#Restate_Insider_link;

\#Restate_link_same_ind=Number of board directors linked to the same industry firms have previously restated financial reports;

Log(\#Restate_link_same_ind $)=\log (1+\#$ Restate_link_same_ind $)$; The natural logarithm of one plus \#Restate_link_same_ind; \#Restate_link_diff_ind= Number of board directors linked to the different industry firms have previously restated financial reports;

Log(\#Restate_link_diff_ind) $=\log (1+$ Restate_link_diff_ind); The natural logarithm of one plus \#Restate_link_diff_ind; 
\#Board_link =Number of board directors in a company that also sit on any other firms' boards;

\#Board_links $01=$ Number of firms that link to the company through board interlocks;

Log(\#Board_link $)=\log (1+\#$ Board_link $)$; The natural logarithm of one plus \#

Board_links;

Log(\#Board_link01) $=\log (1+\#$ Board_links01); The natural logarithm of one plus

\#Board_links01;

$R O A=$ Return on total assets;

$\log (T A)=$ The natural logarithm of total assets;

$M B=$ Market to book Ratio;

$\log ($ SALES $)=$ The natural logarithm of Sales;

Leverage=Leverage, which total liabilities divided by total assets;

Operating_Cycle $=$ Operating cycle which is equal to [360/ (Sales /Average AR) + 360/

(Cost of Goods Sold) / (Average Inventory)].

Log $($ Operating_Cycle $)=$ the natural logarithm of operating cycle;

\#Loss=the frequency of losses in the past seven years;

Big_Auditor=1 if a company is audited by a Big 4/5/6 auditor, and 0 otherwise;

$G$-score=the corporate governance score which is estimated based on Gompers et al. (2003);

$\log (G$-score $)=$ the natural logarithm of G-Score;

CEO_Chair=1, if the CEO is also the chairman of the board, and 0 otherwise;

Board_Size $=$ The size of the corporate board;

Board_Indep=the board independence; the percentage of independent board members;

$\sigma_{-} C F O=$ the standard deviation of cash flows in the past five years deflated by total assets;

$\sigma \_R E V=$ the standard deviation of revenues in the past five years deflated by total assets;

Inst_Holding=Institutional Holdings;

$R_{-}$score $=$The average F-score in the past five year; See Appendix D for the estimation of R-score;

Regulation=1, if the firm's primary SIC code belongs to Telephone industry (4812-4813), TV(4833), Cable (4841), Communication (4811-4899), Gas (4922-4924), Electricity 
(4931), Water (4941), Financial firms (6021-6023, 6035-6036,6141, 6311,6321,6331); and 0 otherwise; See Kasznik and Lev (1995);

Litigation =1, if the firm's primary SIC code belongs to Biotechnology (2833-2836), Computers (7370-7374), Electronics (3600-3674), and Retailing (5200-5961); and 0 otherwise. See Matsumoto (2002).

\section{Appendix B: Estimation of Accruals Quality (AQ)}

We compute accruals quality according to prior studies (e.g.,Dechow and Dichev 2002; McNichols 2002; Francis et al. 2005; Krishnan et al. 2008; Doyle et al. 2007). Specifically, we run the following regressions by industry and year: $\Delta W C_{t}=b_{0}+b_{1} * C F O_{t-1}+b_{2} * C F O_{t}+b_{3} * C F O_{t+1}+b_{4} * \Delta S A L E_{t}+b_{5} P P E_{t}+\varepsilon_{t}$

Where $\triangle W C$ is the change in working capital accruals from year t- 1 to year t. CFO is cash flow from operations. The residuals from the regression measure the extent to which current accruals ( $\triangle W C$ ) do not map into past, present or future cash flows. Following the prior studies, we also include the change of sales ( $\triangle S A L E$ ) and the property, plant and equipment. We first estimate the above regression cross-sectionally by year within each of the SIC 2 digit industry classifications. If an industry group has fewer than 16 observations in any given year, we exclude those observations in that industry-year group. We then calculate the standard deviation of residuals (AQ) for the past seven years that requires a minimum of five years of the data.

\section{Appendix C: Estimation of abnormal (discretionary) accruals (DA ${ }^{\text {PMMJ }}$ )}

I estimate abnormal accruals by using the performance-matched modified-Jones (PMMJ) model. The procedure is similar to that used in previous studies, such as Li et al. (2007) and Kothari et al. (2005). I first compute total accruals using data from the statement of cash flows (Hribar and Collins 2002):

$T_{A c c_{i t}}=E B E I_{i t}-\left(C F O_{i t}-E I D O_{i t}\right)$

where: $T A c c_{i t}=$ firm $i$ 's total accruals in year $t$; 
$E B E I_{i t}=$ firm $i$ 's income before extraordinary items in year $t$;

$C F O_{i t}=$ firm $i$ 's cash flows from operations in year $\mathrm{t}$;

$E I D O_{i t}=$ firm $i$ 's extraordinary items and discontinued operations included in $C F O_{i t}$ in year $t$.

I then estimate discretionary accruals based on the modified-Jones model.

$\operatorname{TAcc}_{i t}=\delta_{0}+\delta_{1}\left(1 /\right.$ Assets $\left._{i, t-1}\right)+\delta_{2}\left(\Delta\right.$ Sales $\left._{i t}-\Delta A R_{i t}\right)+\delta_{3} P P E_{i t}+v_{i t}$

where: Assets $_{i, t-1}=$ firm $i$ 's total assets (in year $t-1$;

$\Delta$ Sales $_{i t}=$ change in firm $i$ 's sales from year $t-1$ to $t$;

$\triangle A R_{i t}=$ change in firm $i$ 's accounts receivable from operating activities from year $t-1$ to $t$;

$P P E_{i t}=$ firm $i$ 's gross property, plant, and equipment in year $t$.

I include $\Delta A R_{i t}$ in the estimation since I have no prior knowledge to identify nonearnings management firms and earnings management firms (e.g., Kothari et al., 2005).

In addition, I exclude all firm-year observations where there are fewer than 16

observations in any two digit SIC code in any given year.

I scale all variables by beginning-of-year total assets.

I define the normal accrual $\left(N A^{M J}{ }_{i t}\right)$ and discretionary accrual $\left(D A^{M J}{ }_{i t}\right)$ metrics as:

$$
\begin{aligned}
N A^{M J}{ }_{i t} & =\hat{\delta}_{0}+\hat{\delta}_{1}\left(1 / \text { Assets }_{i, t-1}\right)+\hat{\delta}_{2}\left(\Delta \text { Sales }_{i t}-\Delta A R_{i t}\right)+\hat{\delta}_{3} P P E_{i t} . \\
D A^{M J}{ }_{i t} & =T A c c_{i t}-N A^{M J}{ }_{i t} \ldots \ldots \ldots \ldots \ldots \ldots \ldots \ldots \ldots \ldots \ldots \ldots \ldots \ldots \ldots \ldots \ldots \ldots \ldots \ldots \ldots \ldots \ldots \ldots \ldots \ldots \ldots \ldots \ldots \ldots \ldots \ldots \ldots \ldots \ldots
\end{aligned}
$$

Finally, for each year, I partition the sample into deciles by ranking firms within the twodigit SIC industries by the current year's return on assets $\left(\mathrm{ROA}_{\mathrm{it}}\right.$ ), which is defined as net income before extraordinary items divided by beginning-of-year total assets. $\mathrm{DA}^{\mathrm{PMMJ}}$ is the difference between firm i's year $t$ modified Jones model accruals and the median value for its joint industry and ROA deciles, where the median calculation excludes firm i. 


\section{Appendix D: Estimation of R-score}

We compute the R-score according to the model developed by Dechow et al. (2009). The estimation of a firm's R-score each year consists of two steps. First, the predicted value is obtained using the following model with the corresponding coefficients for each variable.

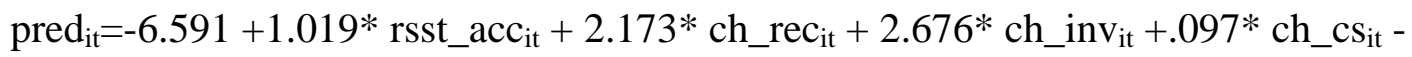
$1.412 *$ ch_earn ${ }_{\mathrm{it}}+.478 *$ issue $-.209 *$ ch_emp $\mathrm{it}_{\mathrm{it}}+.516 *$ leasedum $_{\mathrm{it}}-.134 * \mathrm{bm}_{\mathrm{it}}+.068 *$ ret $_{\mathrm{it}-}$

1

where, rsst_acc ${ }_{i t=}$ firm i’s RSST accruals in year t (see Richardson et al. 2005);

ch_rec it $_{\text {i }}$ firm i’s change in receivables in year t;

ch_invit $=$ firm i's change in inventory in year $\mathrm{t}$;

ch_csit = firm i's change in cash sales in year t;

ch_earn ${ }_{\mathrm{it}}=$ firm i's change in earnings in year t;

issue $=$ an indicator variable which equals 1 if firm I issued securities in year $\mathrm{t}$;

ch_emp it $_{\text {I }}$ firm i's Abnormal change in employees in year t;

leasedum $_{\mathrm{it}}=$ an indicator variable which equals 1 if firm i's future operating lease

obligation are greater than zero in year $\mathrm{t}$;

$\mathrm{bm}_{\mathrm{it}}=$ firm i's book to market ratio in year t;

ret $_{\mathrm{it}-1}=$ firm i's market-adjusted stock return in year t-1;

Then the predicted probability of restatement is calculated as,

Probability $_{i t}=\frac{e^{\text {pred }_{i t}}}{\left(1+e^{\text {pred }_{i t}}\right)}$

The R-score is the ratio of the predicted probability of restatement times 100 . 


\section{References}

Banerjee, A. V. 1992. A Simple-Model of Herd Behavior. Quarterly Journal of Economics 107 (3):797-817.

Bikhchandani, S., D. Hirshleifer, and I. Welch. 1992. A theory of fads, fashion, custom, and cultural-change as informational cascades. Journal of Political Economy 100 (5):992-1026.

Bizjak, J., M. Lemmon, and R. Whitby. 2009. Option Backdating and Board Interlocks. Rev. Financ. Stud.:hhn120.

Davis, G. F. 1991. Agents without Principles? The Spread of the Poison Pill through the Intercorporate Network. Administrative Science Quarterly 36 (4):583.

Dechow, P. M., and I. D. Dichev. 2002. The quality of accruals and earnings: The role of accrual estimation errors. Accounting Review 77:35-59.

Defond, M., J. R. Francis, and X. Hu. 2009. The Geography of Auditor Independence and SEC Enforcement: AAA.

Doyle, J., W. Ge, and S. McVay. 2007. Accruals quality and internal control over financial reporting. Accounting Review 82 (5):1141-1170.

Fich, E. M., and A. Shivdasani. 2007. Financial fraud, director reputation, and shareholder wealth. Journal of Financial Economics 86 (2):306-336.

Francis, J., R. LaFond, P. Olsson, and K. Schipper. 2005. The market pricing of accruals quality. Journal of Accounting \& Economics 39 (2):295-327.

Gleason, C. A., N. T. Jenkins, and W. B. Johnson. 2008. The contagion effects of accounting restatements. Accounting Review 83 (1):83-110.

Gompers, P., J. Ishii, and A. Metrick. 2003. Corporate Governance and Equity Prices. Quarterly Journal of Economics 118 (1):107-155.

Granovetter, M. 1985. Economic-Action and Social-Structure - the Problem of Embeddedness. American Journal of Sociology 91 (3):481-510.

Haunschild, P. R. 1993. Interorganizational imitation - The impact of interlocks on corporate acquisition activity. Administrative Science Quarterly 38 (4):564-592.

Healy, P. M. 1985. The Effect of Bonus Schemes on Accounting Decisions. Journal of Accounting \& Economics 7 (1-3):85-107.

Hennes, K. M., A. J. Leone, and B. P. Miller. 2008. The Importance of Distinguishing Errors from Irregularities in Restatement Research: The Case of Restatements and CEO/CFO. Accounting Review 83 (6):1487-1519.

Hirshleifer, D., and S. H. Teoh. 2003. Herd Behaviour and Cascading in Capital Markets: a Review and Synthesis. European Financial Management 9 (1):25-66. . 2009. Contagion in capital markets. In Handbook of Financial Markets: Dynamics and Evolution, edited by W. Ziemba: Elsevier/North-Holland.

Hribar, P., and D. W. Collins. 2002. Errors in estimating accruals: Implications for empirical research. Journal of Accounting Research 40 (1):105-134.

Hribar, P., and C. Nichols. 2007. The Use of Unsigned Earnings Quality Measures in Tests of Earnings Management. Journal of Accounting Research 45 (5):10171053.

Jones, J. J. 1991. Earnings Management During Import Relief Investigations. Journal of Accounting Research 29 (2):193-228. 
Kasznik, R., and B. Lev. 1995. To warn or not to warn-management disclosures in the face of an earnings surprise. Accounting Review 70 (1):113-134.

Kedia, K., and S. Rajgopal. 2008a. Geography and the incidence of financial misreporting: University of Washington

Kedia, S., and S. Rajgopal. 2008b. Neighborhood Matters: The Impact of Location on Broad Based Option Plans. Journal of Financial Economics Forthcoming.

Kothari, S. P., A. J. Leone, and C. E. Wasley. 2005. Performance matched discretionary accrual measures. Journal of Accounting and Economics 39 (1):163-197.

Krishnan, G. V., B. Srinidhi, and L. Su. 2008. Inventory policy, accruals quality and information risk. Review of Accounting Studies 13 (2-3):369-410.

Li, H., M. P. Pincus, and S. O. Rego. 2007. Market reaction to events surrounding the Sarbanes-Oxley Act of 2002 and earnings management. Journal of Law \& Economics Forthcoming.

Matsumoto, D. A. 2002. Management's incentives to avoid negative earnings surprises. Accounting Review 77 (3):483-514.

McNichols, M. F. 2002. Discussion of the quality of accruals and earnings: The role of accrual estimation errors. Accounting Review 77:61-69.

Palmrose, Z. V., V. J. Richardson, and S. Scholz. 2004. Determinants of market reactions to restatement announcements. Journal of Accounting \& Economics 37 (1):59-89.

Palmrose, Z. V., and S. Scholz. 2004. The circumstances and legal consequences of nonGAAP reporting: Evidence from restatements. Contemporary Accounting Research 21 (1):139-180.

Rao, H., G. F. Davis, and A. Ward. 2000. Embeddedness, social identity and mobility: Why firms leave the NASDAQ and join the New York Stock Exchange. Administrative Science Quarterly 45 (2):268-292.

Richardson, S. A., A. I. Tuna, and M. Wu. 2002. Predicting Earnings Management: The Case of Earnings Restatements: SSRN.

Sah, R. K. 1991. Social Osmosis and Patterns of Crime. Journal of Political Economy 99 (6):1272-1295. 
Table 1 Panel A: Summary Statistics

\begin{tabular}{lcccccc}
\hline \multicolumn{1}{c}{ Variable } & $\mathrm{N}$ & Mean & Median & Std Dev & Q1 & Q3 \\
\hline$A Q$ & 5800 & 0.034 & 0.029 & 0.023 & 0.018 & 0.044 \\
$|\overline{D A}|$ & 5550 & 0.076 & 0.057 & 0.068 & 0.036 & 0.089 \\
\#Restate_link & 6729 & 0.436 & 0.000 & 0.888 & 0.000 & 1.000 \\
\#Restate_link01 & 6729 & 0.405 & 0.000 & 0.802 & 0.000 & 1.000 \\
\#Irregular_link & 6729 & 0.167 & 0.000 & 0.514 & 0.000 & 0.000 \\
\#Board_link & 6729 & 6.543 & 4.000 & 6.982 & 2.000 & 9.000 \\
\#Board_link01 & 6729 & 5.822 & 4.000 & 5.984 & 1.000 & 8.000 \\
ROA & 6729 & 0.028 & 0.042 & 0.114 & 0.009 & 0.081 \\
\#Loss & 6729 & 0.203 & 0.000 & 0.402 & 0.000 & 0.000 \\
Log(TA) & 6729 & 7.258 & 7.062 & 1.492 & 6.175 & 8.196 \\
Log(SALES) & 6729 & 7.147 & 7.026 & 1.461 & 6.147 & 8.079 \\
Leverage & 6729 & 0.541 & 0.556 & 0.220 & 0.388 & 0.689 \\
MB & 6729 & 3.223 & 2.172 & 3.596 & 1.384 & 3.780 \\
Log(Operating_Cycle) & 6729 & 4.691 & 4.728 & 0.708 & 4.315 & 5.103 \\
G_CFO & 6382 & 0.062 & 0.047 & 0.053 & 0.027 & 0.079 \\
G_REV & 6185 & 0.251 & 0.168 & 0.257 & 0.089 & 0.310 \\
R_score & 6669 & 0.418 & 0.392 & 0.167 & 0.327 & 0.472 \\
Big_Auditor & 6729 & 0.977 & 1.000 & 0.149 & 1.000 & 1.000 \\
Log(G-score) & 5896 & 2.262 & 2.303 & 0.292 & 2.079 & 2.485 \\
Inst_Holding & 6531 & 0.161 & 0.142 & 0.127 & 0.061 & 0.238 \\
Regulation & 6729 & 0.076 & 0.000 & 0.265 & 0.000 & 0.000 \\
Litigation & 6729 & 0.308 & 0.000 & 0.462 & 0.000 & 1.000 \\
CEO_Chair & 6700 & 0.656 & 1.000 & 0.475 & 0.000 & 1.000 \\
Board_Size & 6700 & 9.171 & 9.000 & 2.636 & 7.000 & 11.000 \\
Board_indep & 6700 & 0.613 & 0.636 & 0.002 & 0.500 & 0.769 \\
\hline
\end{tabular}

* All continuous variables are winsorized at $1 \%$ and $99 \%$ level; All the variable definitions are included in Appendix $A$; 
Table 1 Panel B Pearson Correlation Table

\begin{tabular}{|c|c|c|c|c|c|c|c|c|c|c|c|c|c|c|c|c|c|c|c|c|}
\hline Log(\#restate_link) & $\mathrm{A}$ & $\mathrm{A}$ & $\mathrm{B}$ & $C$ & $\mathrm{D}$ & $\mathrm{E}$ & $\mathrm{F}$ & $\mathrm{G}$ & $\mathrm{H}$ & 1 & $\mathrm{~J}$ & $\mathrm{~K}$ & $\mathrm{~L}$ & $M$ & $\mathrm{~N}$ & $\mathrm{O}$ & $\mathrm{P}$ & $\mathrm{Q}$ & $\mathrm{R}$ & $\mathrm{s}$ \\
\hline \multirow[t]{2}{*}{ Log(\#Board_Link) } & $\mathrm{B}$ & 0.421 & & & & & & & & & & & & & & & & & & \\
\hline & & $<.0001$ & & & & & & & & & & & & & & & & & & \\
\hline \multirow[t]{2}{*}{$R O A$} & $\mathrm{C}$ & -0.008 & 0.076 & & & & & & & & & & & & & & & & & \\
\hline & & 0.500 & $<.0001$ & & & & & & & & & & & & & & & & & \\
\hline \multirow[t]{2}{*}{ \#Loss } & $\mathrm{D}$ & 0.012 & -0.098 & -0.689 & & & & & & & & & & & & & & & & \\
\hline & & 0.326 & $<.0001$ & $<.0001$ & & & & & & & & & & & & & & & & \\
\hline \multirow[t]{2}{*}{$\log (T A)$} & $E$ & 0.321 & 0.579 & 0.115 & -0.159 & & & & & & & & & & & & & & & \\
\hline & & $<.0001$ & $<.0001$ & $<.0001$ & $<.0001$ & & & & & & & & & & & & & & & \\
\hline \multirow[t]{2}{*}{$\log (S A L E S)$} & $\mathrm{F}$ & 0.316 & 0.592 & 0.235 & -0.245 & 0.884 & & & & & & & & & & & & & & \\
\hline & & $<.0001$ & $<.0001$ & $<.0001$ & $<.0001$ & $<.0001$ & & & & & & & & & & & & & & \\
\hline \multirow[t]{2}{*}{ Leverage } & $\mathrm{G}$ & 0.138 & 0.327 & -0.166 & 0.035 & 0.446 & 0.422 & & & & & & & & & & & & & \\
\hline & & $<.0001$ & $<.0001$ & $<.0001$ & 0.004 & $<.0001$ & $<.0001$ & & & & & & & & & & & & & \\
\hline \multirow[t]{2}{*}{ MB } & $\mathrm{H}$ & 0.054 & 0.131 & 0.210 & -0.129 & 0.095 & 0.100 & -0.044 & & & & & & & & & & & & \\
\hline & & $<.0001$ & $<.0001$ & $<.0001$ & $<.0001$ & $<.0001$ & $<.0001$ & 0.000 & & & & & & & & & & & & \\
\hline \multirow[t]{2}{*}{ Log(Operating Cycle) } & I & 0.033 & 0.040 & -0.049 & 0.037 & 0.054 & -0.088 & 0.001 & -0.001 & & & & & & & & & & & \\
\hline & & 0.007 & 0.001 & $<.0001$ & 0.002 & $<.0001$ & $<.0001$ & 0.903 & 0.940 & & & & & & & & & & & \\
\hline \multirow[t]{2}{*}{$\sigma_{-} C F O$} & $\mathrm{~J}$ & -0.071 & -0.248 & -0.254 & 0.260 & -0.314 & -0.317 & -0.225 & 0.074 & -0.043 & & & & & & & & & & \\
\hline & & $<.0001$ & $<.0001$ & $<.0001$ & $<.0001$ & $<.0001$ & $<.0001$ & $<.0001$ & $<.0001$ & 0.001 & & & & & & & & & & \\
\hline \multirow[t]{2}{*}{$\sigma_{-} R E V$} & $\mathrm{~K}$ & -0.036 & -0.161 & -0.155 & 0.158 & -0.153 & -0.043 & -0.070 & -0.021 & -0.166 & 0.490 & & & & & & & & & \\
\hline & & 0.004 & $<.0001$ & $<.0001$ & $<.0001$ & $<.0001$ & 0.001 & $<.0001$ & 0.101 & $<.0001$ & $<.0001$ & & & & & & & & & \\
\hline \multirow[t]{2}{*}{ R_score } & $\mathrm{L}$ & -0.057 & -0.180 & -0.186 & 0.174 & -0.132 & -0.144 & -0.249 & 0.128 & 0.097 & 0.458 & 0.485 & & & & & & & & \\
\hline & & $<.0001$ & $<.0001$ & $<.0001$ & $<.0001$ & $<.0001$ & $<.0001$ & $<.0001$ & $<.0001$ & $<.0001$ & $<.0001$ & $<.0001$ & & & & & & & & \\
\hline \multirow[t]{2}{*}{ Big_Auditor } & M & 0.036 & 0.127 & -0.027 & 0.022 & 0.084 & 0.070 & 0.090 & 0.046 & -0.045 & -0.025 & 0.008 & 0.004 & & & & & & & \\
\hline & & 0.004 & $<.0001$ & 0.029 & 0.070 & $<.0001$ & $<.0001$ & $<.0001$ & 0.000 & 0.000 & 0.046 & 0.522 & 0.756 & & & & & & & \\
\hline \multirow[t]{2}{*}{$\log (G$-score $)$} & $N$ & 0.103 & 0.279 & 0.058 & -0.072 & 0.153 & 0.187 & 0.150 & -0.046 & 0.012 & -0.194 & -0.079 & -0.188 & 0.042 & & & & & & \\
\hline & & $<.0001$ & $<.0001$ & $<.0001$ & $<.0001$ & $<.0001$ & $<.0001$ & $<.0001$ & 0.001 & 0.356 & $<.0001$ & $<.0001$ & $<.0001$ & 0.001 & & & & & & \\
\hline \multirow[t]{2}{*}{ Inst_Holding } & $\mathrm{O}$ & -0.026 & -0.105 & -0.050 & 0.091 & -0.188 & -0.162 & 0.001 & -0.124 & 0.025 & 0.042 & 0.075 & 0.005 & -0.014 & -0.062 & & & & & \\
\hline & & 0.039 & $<.0001$ & $<.0001$ & $<.0001$ & $<.0001$ & $<.0001$ & 0.918 & $<.0001$ & 0.042 & 0.001 & $<.0001$ & 0.684 & 0.269 & $<.0001$ & & & & & \\
\hline \multirow[t]{2}{*}{ Regulation } & $\mathrm{P}$ & -0.018 & 0.017 & -0.043 & -0.024 & 0.233 & 0.068 & 0.211 & -0.085 & -0.051 & -0.143 & -0.119 & -0.192 & 0.036 & 0.024 & -0.104 & & & & \\
\hline & & 0.133 & 0.166 & 0.000 & 0.054 & $<.0001$ & $<.0001$ & $<.0001$ & $<.0001$ & $<.0001$ & $<.0001$ & $<.0001$ & $<.0001$ & 0.003 & 0.060 & $<.0001$ & & & & \\
\hline \multirow[t]{2}{*}{ Litigation } & $\mathrm{Q}$ & -0.014 & -0.154 & -0.106 & 0.136 & -0.141 & -0.107 & -0.332 & 0.157 & -0.034 & 0.303 & 0.113 & 0.306 & 0.011 & -0.143 & -0.012 & -0.191 & & & \\
\hline & & 0.252 & $<.0001$ & $<.0001$ & $<.0001$ & $<.0001$ & $<.0001$ & $<.0001$ & $<.0001$ & 0.005 & $<.0001$ & $<.0001$ & $<.0001$ & 0.389 & $<.0001$ & 0.318 & $<.0001$ & & & \\
\hline \multirow[t]{2}{*}{ CEO_Chair } & $\mathrm{R}$ & 0.067 & 0.124 & 0.023 & -0.038 & 0.145 & 0.149 & 0.101 & 0.028 & 0.001 & -0.060 & -0.027 & -0.026 & 0.029 & 0.105 & -0.018 & 0.030 & -0.047 & & \\
\hline & & $<.0001$ & $<.0001$ & 0.063 & 0.002 & $<.0001$ & $<.0001$ & $<.0001$ & 0.023 & 0.962 & $<.0001$ & 0.037 & 0.036 & 0.018 & $<.0001$ & 0.152 & 0.014 & 0.000 & & \\
\hline \multirow[t]{2}{*}{ Board_Size } & $\mathrm{s}$ & 0.223 & 0.545 & 0.126 & -0.165 & 0.563 & 0.548 & 0.327 & 0.043 & 0.015 & -0.332 & -0.189 & -0.245 & 0.040 & 0.238 & -0.165 & 0.130 & -0.228 & 0.040 & \\
\hline & & $<.0001$ & $<.0001$ & $<.0001$ & $<.0001$ & $<.0001$ & $<.0001$ & $<.0001$ & 0.001 & 0.234 & $<.0001$ & $<.0001$ & $<.0001$ & 0.001 & $<.0001$ & $<.0001$ & $<.0001$ & $<.0001$ & 0.001 & \\
\hline \multirow[t]{2}{*}{ Board_Indep } & $\mathrm{T}$ & 0.197 & 0.330 & -0.019 & -0.009 & 0.168 & 0.153 & 0.140 & 0.000 & 0.011 & -0.082 & -0.061 & -0.141 & 0.086 & 0.294 & 0.026 & 0.015 & -0.061 & 0.158 & 0.086 \\
\hline & & $<.0001$ & $<.0001$ & 0.125 & 0.470 & $<.0001$ & $<.0001$ & $<.0001$ & 0.994 & 0.356 & $<.0001$ & $<.0001$ & $<.0001$ & $<.0001$ & $<.0001$ & 0.036 & 0.215 & $<.0001$ & $<.0001$ & $<.0001$ \\
\hline
\end{tabular}


Table 2: Regression Results using Accruals Quality (AQ) as the dependent Variable

\begin{tabular}{|c|c|c|c|c|c|c|}
\hline Variables & Pred. & (1) & (2) & (3) & (4) & (5) \\
\hline Restate-link_0/1 & + & & & & & $\begin{array}{c}0.002 \\
(0.0034)\end{array}$ \\
\hline Log(\#Restate-link) & + & & $\begin{array}{c}0.002 \\
(0.0018)\end{array}$ & $\begin{array}{c}0.003 \\
(<.0001)\end{array}$ & $\begin{array}{c}0.002 \\
(0.0014)\end{array}$ & \\
\hline Log(\#Board-link) & - & $\begin{array}{c}-0.003 \\
(<.0001)\end{array}$ & & $\begin{array}{c}-0.003 \\
(<.0001)\end{array}$ & $\begin{array}{c}-0.000 \\
(0.2059)\end{array}$ & $\begin{array}{c}-0.000 \\
(0.2314)\end{array}$ \\
\hline$R O A$ & & $\begin{array}{c}-0.038 \\
(<.0001)\end{array}$ & $\begin{array}{c}-0.037 \\
(<.0001)\end{array}$ & $\begin{array}{c}-0.038 \\
(<.0001)\end{array}$ & $\begin{array}{c}-0.010 \\
(0.0063)\end{array}$ & $\begin{array}{c}-0.010 \\
(0.0064)\end{array}$ \\
\hline \#Loss & & $\begin{array}{c}0.005 \\
(<.0001)\end{array}$ & $\begin{array}{c}0.005 \\
(<.0001)\end{array}$ & $\begin{array}{c}0.005 \\
(<.0001)\end{array}$ & $\begin{array}{c}0.001 \\
(0.2598)\end{array}$ & $\begin{array}{c}0.001 \\
(0.2413)\end{array}$ \\
\hline $\log (T A)$ & & $\begin{array}{c}-0.010 \\
(<.0001)\end{array}$ & $\begin{array}{c}-0.011 \\
(<.0001)\end{array}$ & $\begin{array}{c}-0.010 \\
(<.0001)\end{array}$ & $\begin{array}{c}-0.008 \\
(<.0001)\end{array}$ & $\begin{array}{c}-0.008 \\
(<.0001)\end{array}$ \\
\hline $\log (S A L E S)$ & & $\begin{array}{c}0.008 \\
(<.0001)\end{array}$ & $\begin{array}{c}0.007 \\
(<.0001)\end{array}$ & $\begin{array}{c}0.008 \\
(<.0001)\end{array}$ & $\begin{array}{c}0.006 \\
(<.0001)\end{array}$ & $\begin{array}{c}0.006 \\
(<.0001)\end{array}$ \\
\hline Leverage & & $\begin{array}{c}-0.011 \\
(<.0001)\end{array}$ & $\begin{array}{c}-0.011 \\
(<.0001)\end{array}$ & $\begin{array}{c}-0.010 \\
(<.0001)\end{array}$ & $\begin{array}{c}0.003 \\
(0.0501)\end{array}$ & $\begin{array}{c}0.003 \\
(0.0541)\end{array}$ \\
\hline$M B$ & & $\begin{array}{c}0.001 \\
(<.0001)\end{array}$ & $\begin{array}{c}0.001 \\
(<.0001)\end{array}$ & $\begin{array}{c}0.001 \\
(<.0001)\end{array}$ & $\begin{array}{c}0.000 \\
(0.1012)\end{array}$ & $\begin{array}{c}0.000 \\
(0.1)\end{array}$ \\
\hline Log(Operating_Cycle) & & $\begin{array}{c}0.007 \\
(<.0001)\end{array}$ & $\begin{array}{c}0.006 \\
(<.0001)\end{array}$ & $\begin{array}{c}0.007 \\
(<.0001)\end{array}$ & $\begin{array}{c}0.007 \\
(<.0001)\end{array}$ & $\begin{array}{c}0.007 \\
(<.0001)\end{array}$ \\
\hline$\sigma_{-} C F O$ & & & & & $\begin{array}{c}0.158 \\
(<.0001)\end{array}$ & $\begin{array}{c}0.158 \\
(<.0001)\end{array}$ \\
\hline$\sigma \_R E V$ & & & & & $\begin{array}{c}0.012 \\
(<.0001)\end{array}$ & $\begin{array}{c}0.012 \\
(<.0001)\end{array}$ \\
\hline$R \_s c o r e$ & & & & & $\begin{array}{c}0.016 \\
(<.0001)\end{array}$ & $\begin{array}{c}0.016 \\
(<.0001)\end{array}$ \\
\hline Big_Auditor & & $\begin{array}{c}0.001 \\
(0.5434)\end{array}$ & $\begin{array}{c}0.000 \\
(0.9660)\end{array}$ & $\begin{array}{c}0.001 \\
(0.4606)\end{array}$ & $\begin{array}{c}-0.002 \\
(0.3465)\end{array}$ & $\begin{array}{c}-0.002 \\
(0.3468)\end{array}$ \\
\hline $\log (G$-score $)$ & & & & & $\begin{array}{c}-0.001 \\
(0.1221)\end{array}$ & $\begin{array}{c}-0.001 \\
(0.1203)\end{array}$ \\
\hline Inst_Holding & & & & & $\begin{array}{c}0.003 \\
(0.1523)\end{array}$ & $\begin{array}{c}0.003 \\
(0.157)\end{array}$ \\
\hline Regulation & & & & & $\begin{array}{c}-0.000 \\
(0.6997)\end{array}$ & $\begin{array}{c}-0.000 \\
(0.6934)\end{array}$ \\
\hline Litigation & & & & & $\begin{array}{c}0.002 \\
(0.0005)\end{array}$ & $\begin{array}{c}0.002 \\
(0.0005)\end{array}$ \\
\hline CEO_Chair & & & & & $\begin{array}{c}-0.001 \\
(0.2457)\end{array}$ & $\begin{array}{c}-0.001 \\
(0.2403)\end{array}$ \\
\hline Board_Size & & & & & $\begin{array}{c}-0.000 \\
(0.0029)\end{array}$ & $\begin{array}{c}-0.000 \\
(0.0032)\end{array}$ \\
\hline Board_Indep & & & & & $\begin{array}{c}-0.000 \\
(0.0586)\end{array}$ & $\begin{array}{c}-0.000 \\
(0.0633)\end{array}$ \\
\hline Intercept & & $\begin{array}{c}0.0289 \\
(<.0001)\end{array}$ & $\begin{array}{c}0.036 \\
(<.0001)\end{array}$ & $\begin{array}{c}0.030 \\
(<.0001)\end{array}$ & $\begin{array}{c}0.007 \\
(0.0557)\end{array}$ & $\begin{array}{c}0.007 \\
(0.0649)\end{array}$ \\
\hline $\begin{array}{l}\text { Adjusted } R^{2} \\
\# \text { of Obs }\end{array}$ & & $\begin{array}{c}22.50 \% \\
5,800\end{array}$ & $\begin{array}{c}21.99 \% \\
5,800\end{array}$ & $\begin{array}{c}22.83 \% \\
5,800\end{array}$ & $\begin{array}{c}39.78 \% \\
5,023\end{array}$ & $\begin{array}{c}39.76 \% \\
5,023\end{array}$ \\
\hline
\end{tabular}

Notes: $p$-values are in parentheses, and are one-tailed if there is a directional prediction; two-tailed otherwise; all the variable definitions are included in Appendix A; 
Table 3: Regression results using $|\overline{D A}|$ as the dependent variable

\begin{tabular}{|c|c|c|c|c|c|c|}
\hline Variables & Pred. & (1) & (2) & (3) & (4) & (5) \\
\hline Restate-link_0/1 & + & & & & & $\begin{array}{c}0.010 \\
(<.0001)\end{array}$ \\
\hline Log(\#Restate_link) & + & & $\begin{array}{c}0.009 \\
(<.0001)\end{array}$ & $\begin{array}{c}0.015 \\
(<.0001)\end{array}$ & $\begin{array}{c}0.010 \\
(<.0001)\end{array}$ & \\
\hline Log(\#Board_link) & - & $\begin{array}{c}-0.008 \\
(<.0001)\end{array}$ & & $\begin{array}{c}-0.010 \\
(<.0001)\end{array}$ & $\begin{array}{c}-0.004 \\
(0.0013)\end{array}$ & $\begin{array}{c}-0.004 \\
(0.0012)\end{array}$ \\
\hline$R O A$ & & $\begin{array}{c}-0.134 \\
(<.0001)\end{array}$ & $\begin{array}{c}-0.131 \\
(<.0001)\end{array}$ & $\begin{array}{c}-0.133 \\
(<.0001)\end{array}$ & $\begin{array}{c}-0.039 \\
(0.0013)\end{array}$ & $\begin{array}{c}-0.039 \\
(0.0014)\end{array}$ \\
\hline \#Loss & & $\begin{array}{c}0.017 \\
(<.0001)\end{array}$ & $\begin{array}{c}0.016 \\
(<.0001)\end{array}$ & $\begin{array}{c}0.016 \\
(<.0001)\end{array}$ & $\begin{array}{c}0.008 \\
(0.0037)\end{array}$ & $\begin{array}{c}0.008 \\
(0.0031)\end{array}$ \\
\hline $\log (T A)$ & & $\begin{array}{c}-0.004 \\
(0.0085)\end{array}$ & $\begin{array}{c}-0.005 \\
(0.0002)\end{array}$ & $\begin{array}{c}-0.004 \\
(0.0024)\end{array}$ & $\begin{array}{c}0.002 \\
(0.1093)\end{array}$ & $\begin{array}{c}0.002 \\
(0.0944)\end{array}$ \\
\hline $\log (S A L E S)$ & & $\begin{array}{c}0.004 \\
(0.0033)\end{array}$ & $\begin{array}{c}0.002 \\
(0.201)\end{array}$ & $\begin{array}{c}0.004 \\
(0.0046)\end{array}$ & $\begin{array}{c}-0.004 \\
(0.0108)\end{array}$ & $\begin{array}{c}-0.004 \\
(0.0107)\end{array}$ \\
\hline$M B$ & & $\begin{array}{c}0.004 \\
(<.0001)\end{array}$ & $\begin{array}{c}0.004 \\
(<.0001)\end{array}$ & $\begin{array}{c}0.004 \\
(<.0001)\end{array}$ & $\begin{array}{c}0.002 \\
(<.0001)\end{array}$ & $\begin{array}{c}0.002 \\
(<.0001)\end{array}$ \\
\hline Leverage & & $\begin{array}{c}-0.092 \\
(<.0001)\end{array}$ & $\begin{array}{c}-0.095 \\
(<.0001)\end{array}$ & $\begin{array}{c}-0.090 \\
(<.0001)\end{array}$ & $\begin{array}{c}-0.030 \\
(<.0001)\end{array}$ & $\begin{array}{c}-0.030 \\
(<.0001)\end{array}$ \\
\hline Log(Operating_Cycle) & & $\begin{array}{c}-0.005 \\
(0.0005)\end{array}$ & $\begin{array}{c}-0.006 \\
(<.0001)\end{array}$ & $\begin{array}{c}-0.005 \\
(0.0004)\end{array}$ & $\begin{array}{c}-0.009 \\
(<.0001)\end{array}$ & $\begin{array}{c}-0.009 \\
(<.0001)\end{array}$ \\
\hline$\sigma_{-} C F O$ & & & & & $\begin{array}{c}0.340 \\
(<.0001)\end{array}$ & $\begin{array}{c}0.341 \\
(<.0001)\end{array}$ \\
\hline$\sigma_{-} R E V$ & & & & & $\begin{array}{c}0.002 \\
(0.6355)\end{array}$ & $\begin{array}{c}0.002 \\
(0.6282)\end{array}$ \\
\hline R_score & & & & & $\begin{array}{c}0.114 \\
(<.0001)\end{array}$ & $\begin{array}{c}0.114 \\
(<.0001)\end{array}$ \\
\hline Big_Auditor & & $\begin{array}{c}0.009 \\
(0.104)\end{array}$ & $\begin{array}{c}0.005 \\
(0.3278)\end{array}$ & $\begin{array}{c}0.010 \\
(0.0701)\end{array}$ & $\begin{array}{c}0.000 \\
(0.9556)\end{array}$ & $\begin{array}{c}0.000 \\
(0.9295)\end{array}$ \\
\hline Log(G-score) & & & & & $\begin{array}{c}0.005 \\
(0.0703)\end{array}$ & $\begin{array}{c}0.005 \\
(0.0734)\end{array}$ \\
\hline Inst_Holding & & & & & $\begin{array}{c}-0.011 \\
(0.0943)\end{array}$ & $\begin{array}{c}-0.011 \\
(0.0913)\end{array}$ \\
\hline Regulation & & & & & $\begin{array}{c}-0.011 \\
(0.0026)\end{array}$ & $\begin{array}{c}-0.011 \\
(0.0026)\end{array}$ \\
\hline Litigation & & & & & $\begin{array}{c}0.015 \\
(<.0001)\end{array}$ & $\begin{array}{c}0.015 \\
(<.0001)\end{array}$ \\
\hline CEO_Chair & & & & & $\begin{array}{c}-0.002 \\
(0.2503)\end{array}$ & $\begin{array}{c}-0.002 \\
(0.2426)\end{array}$ \\
\hline Board_Size & & & & & $\begin{array}{c}-0.001 \\
(0.0515)\end{array}$ & $\begin{array}{c}-0.001 \\
(0.0646)\end{array}$ \\
\hline Board_Indep & & & & & $\begin{array}{c}0.000 \\
(0.1441)\end{array}$ & $\begin{array}{c}0.000 \\
(0.1433)\end{array}$ \\
\hline Intercept & & $\begin{array}{c}0.135 \\
(<.0001)\end{array}$ & $\begin{array}{c}0.161 \\
(<.0001)\end{array}$ & $\begin{array}{c}0.139 \\
(<.0001)\end{array}$ & $\begin{array}{c}0.067 \\
(<.0001)\end{array}$ & $\begin{array}{c}0.066 \\
(<.0001)\end{array}$ \\
\hline $\begin{array}{l}\text { Adjusted } R^{2} \\
\text { \# of Obs }\end{array}$ & & $\begin{array}{l}13.0 \% \\
5,305\end{array}$ & $\begin{array}{c}12.9 \% \\
5,305\end{array}$ & $\begin{array}{l}13.6 \% \\
5,305\end{array}$ & $\begin{array}{l}21.3 \% \\
4,653\end{array}$ & $\begin{array}{l}20.5 \% \\
4,734\end{array}$ \\
\hline
\end{tabular}

Notes: $p$-values are in parentheses, and are one-tailed if there is a directional prediction; two-tailed otherwise; all the variable definitions are included in Appendix A; 
Table 4: Logistic Regression (Dependable Variable is Restate_0/1)

\begin{tabular}{|c|c|c|c|c|c|c|}
\hline Variables & Pred. & (1) & (2) & (3) & (4) & (5) \\
\hline Restate-link_0/1 & + & & & & & $\begin{array}{c}0.718 \\
(0.0001)\end{array}$ \\
\hline Log(\#Restate_link) & + & & $\begin{array}{c}0.506 \\
(0.0007)\end{array}$ & $\begin{array}{c}0.753 \\
(<.0001)\end{array}$ & $\begin{array}{c}0.817 \\
(<.0001)\end{array}$ & \\
\hline Log(\#Board_link) & - & $\begin{array}{c}-0.265 \\
(0.0039) \\
\end{array}$ & & $\begin{array}{c}-0.424 \\
(<.0001) \\
\end{array}$ & $\begin{array}{c}-0.426 \\
(0.0009) \\
\end{array}$ & $\begin{array}{c}-0.396 \\
(0.0018) \\
\end{array}$ \\
\hline$R O A$ & & $\begin{array}{c}-2.087 \\
(0.0044)\end{array}$ & $\begin{array}{l}-1.900 \\
(0.0095)\end{array}$ & $\begin{array}{c}-1.958 \\
(0.0076)\end{array}$ & $\begin{array}{c}-0.469 \\
(0.6374)\end{array}$ & $\begin{array}{l}-0.479 \\
(0.6318)\end{array}$ \\
\hline \#Loss & & $\begin{array}{c}0.298 \\
(0.1842)\end{array}$ & $\begin{array}{c}0.248 \\
(0.2709)\end{array}$ & $\begin{array}{c}0.246 \\
(0.2732)\end{array}$ & $\begin{array}{c}0.216 \\
(0.3979)\end{array}$ & $\begin{array}{c}0.233 \\
(0.3637)\end{array}$ \\
\hline $\log (T A)$ & & $\begin{array}{c}-0.021 \\
(0.8476)\end{array}$ & $\begin{array}{l}-0.070 \\
(0.5371)\end{array}$ & $\begin{array}{c}-0.041 \\
(0.7122)\end{array}$ & $\begin{array}{l}0.030 \\
(0.84)\end{array}$ & $\begin{array}{c}0.048 \\
(0.7428)\end{array}$ \\
\hline $\log (S A L E S)$ & & $\begin{array}{c}0.297 \\
(0.0149)\end{array}$ & $\begin{array}{c}0.176 \\
(0.149)\end{array}$ & $\begin{array}{c}0.272 \\
(0.0271)\end{array}$ & $\begin{array}{c}0.186 \\
(0.2318)\end{array}$ & $\begin{array}{c}0.189 \\
(0.2211)\end{array}$ \\
\hline$M B$ & & $\begin{array}{c}-0.030 \\
(0.2114)\end{array}$ & $\begin{array}{l}-0.038 \\
(0.1129)\end{array}$ & $\begin{array}{l}-0.030 \\
(0.2122)\end{array}$ & $\begin{array}{c}-0.053 \\
(0.0815)\end{array}$ & $\begin{array}{c}-0.053 \\
(0.0793)\end{array}$ \\
\hline Leverage & & $\begin{array}{c}0.322 \\
(0.3952)\end{array}$ & $\begin{array}{c}0.311 \\
(0.4088)\end{array}$ & $\begin{array}{c}0.426 \\
(0.2583)\end{array}$ & $\begin{array}{c}0.707 \\
(0.1344)\end{array}$ & $\begin{array}{c}0.677 \\
(0.1534)\end{array}$ \\
\hline Log(Operating_Cycle) & & $\begin{array}{c}0.260 \\
(0.0215)\end{array}$ & $\begin{array}{c}0.227 \\
(0.0483)\end{array}$ & $\begin{array}{c}0.250 \\
(0.028)\end{array}$ & $\begin{array}{c}0.240 \\
(0.0847)\end{array}$ & $\begin{array}{c}0.239 \\
(0.0862)\end{array}$ \\
\hline$\sigma \_C F O$ & & & & & $\begin{array}{c}1.872 \\
(0.3457)\end{array}$ & $\begin{array}{l}1.907 \\
(0.337)\end{array}$ \\
\hline$\sigma \_R E V$ & & & & & $\begin{array}{c}0.145 \\
(0.715)\end{array}$ & $\begin{array}{c}0.149 \\
(0.7068)\end{array}$ \\
\hline R_score & & & & & $\begin{array}{c}1.100 \\
(0.0814)\end{array}$ & $\begin{array}{c}1.083 \\
(0.0845)\end{array}$ \\
\hline Big_Auditor & & $\begin{array}{c}0.796 \\
(0.2701)\end{array}$ & $\begin{array}{c}0.642 \\
(0.372)\end{array}$ & $\begin{array}{c}0.847 \\
(0.2407)\end{array}$ & $\begin{array}{c}0.498 \\
(0.4942)\end{array}$ & $\begin{array}{c}0.493 \\
(0.4991)\end{array}$ \\
\hline Log(G-score) & & & & & $\begin{array}{c}0.959 \\
(0.0038)\end{array}$ & $\begin{array}{c}0.955 \\
(0.0039)\end{array}$ \\
\hline Inst_Holding & & & & & $\begin{array}{c}0.691 \\
(0.2999)\end{array}$ & $\begin{array}{c}0.688 \\
(0.3001)\end{array}$ \\
\hline Regulation & & & & & $\begin{array}{c}0.715 \\
(0.0268)\end{array}$ & $\begin{array}{c}0.711 \\
(0.0272)\end{array}$ \\
\hline Litigation & & & & & $\begin{array}{c}0.574 \\
(0.0039)\end{array}$ & $\begin{array}{c}0.579 \\
(0.0038)\end{array}$ \\
\hline CEO_Chair & & & & & $\begin{array}{c}-0.131 \\
(0.4634)\end{array}$ & $\begin{array}{c}-0.135 \\
(0.4488)\end{array}$ \\
\hline Board_Size & & & & & $\begin{array}{c}-0.026 \\
(0.5388)\end{array}$ & $\begin{array}{c}-0.022 \\
(0.6027)\end{array}$ \\
\hline Board_Indep & & & & & $\begin{array}{c}0.004 \\
(0.3902)\end{array}$ & $\begin{array}{c}0.005 \\
(0.3176)\end{array}$ \\
\hline Intercept & & $\begin{array}{c}-7.278 \\
(<.0001)\end{array}$ & $\begin{array}{c}-6.275 \\
(<.0001)\end{array}$ & $\begin{array}{c}-6.977 \\
(<.0001)\end{array}$ & $\begin{array}{c}-9.718 \\
(<.0001)\end{array}$ & $\begin{array}{c}-9.951 \\
(<.0001)\end{array}$ \\
\hline $\begin{array}{l}\text { Max-rescaled } \mathrm{R}^{2} \\
\# \text { of Obs }\end{array}$ & & $\begin{array}{l}3.15 \% \\
6,729\end{array}$ & $\begin{array}{l}3.33 \% \\
6,729\end{array}$ & $\begin{array}{l}4.32 \% \\
6,729 \\
\end{array}$ & $\begin{array}{l}6.79 \% \\
5,399\end{array}$ & $\begin{array}{l}6.46 \% \\
5,399\end{array}$ \\
\hline
\end{tabular}

Notes: $p$-values are in parentheses, and are one-tailed if there is a directional prediction; two-tailed otherwise; all the variable definitions are included in Appendix A; 
Table 5 Regressions using Accounting Irregularities (1997-2002):

\begin{tabular}{|c|c|c|c|c|}
\hline & & (1) & (2) & (3) \\
\hline Variables & Pred. & $\mathrm{AQ}$ & $|\overline{D A}|$ & Irregularities_0/1 \\
\hline Log(\#lrregular_link) & + & $\begin{array}{c}0.002 \\
(0.0068)\end{array}$ & $\begin{array}{c}0.009 \\
(0.0003)\end{array}$ & $\begin{array}{c}0.760 \\
(0.0008)\end{array}$ \\
\hline Log(\#Board_link) & - & $\begin{array}{c}-0.000 \\
(0.0068)\end{array}$ & $\begin{array}{c}-0.003 \\
(0.0107)\end{array}$ & $\begin{array}{c}-0.332 \\
(0.0059)\end{array}$ \\
\hline$R O A$ & & $\begin{array}{c}-0.010 \\
(0.0066)\end{array}$ & $\begin{array}{c}-0.040 \\
(0.0011)\end{array}$ & $\begin{array}{c}-0.503 \\
(0.6136)\end{array}$ \\
\hline \#Loss & & $\begin{array}{c}0.001 \\
(0.2194)\end{array}$ & $\begin{array}{c}0.009 \\
(0.0021)\end{array}$ & $\begin{array}{c}0.252 \\
(0.3246)\end{array}$ \\
\hline $\log (T A)$ & & $\begin{array}{c}-0.008 \\
(<.0001)\end{array}$ & $\begin{array}{c}0.003 \\
(0.0833)\end{array}$ & $\begin{array}{c}0.040 \\
(0.784)\end{array}$ \\
\hline $\log (S A L E S)$ & & $\begin{array}{c}0.006 \\
(<.0001)\end{array}$ & $\begin{array}{c}-0.004 \\
(0.0148)\end{array}$ & $\begin{array}{c}0.207 \\
(0.1821)\end{array}$ \\
\hline MB & & $\begin{array}{c}0.000 \\
(0.1009)\end{array}$ & $\begin{array}{c}0.002 \\
(<.0001)\end{array}$ & $\begin{array}{c}-0.053 \\
(0.0835)\end{array}$ \\
\hline Leverage & & $\begin{array}{c}0.003 \\
(0.0606)\end{array}$ & $\begin{array}{c}-0.031 \\
(<.0001)\end{array}$ & $\begin{array}{c}0.622 \\
(0.1884)\end{array}$ \\
\hline Log(Operating_Cycle) & & $\begin{array}{c}0.007 \\
(<.0001)\end{array}$ & $\begin{array}{c}-0.009 \\
(<.0001)\end{array}$ & $\begin{array}{c}0.256 \\
(0.0678)\end{array}$ \\
\hline$\sigma_{-} C F O$ & & $\begin{array}{c}0.158 \\
(<.0001)\end{array}$ & $\begin{array}{c}0.342 \\
(<.0001)\end{array}$ & $\begin{array}{c}2.026 \\
(0.3031)\end{array}$ \\
\hline$\sigma \_R E V$ & & $\begin{array}{c}0.012 \\
(<.0001)\end{array}$ & $\begin{array}{c}0.002 \\
(0.6323)\end{array}$ & $\begin{array}{c}0.143 \\
(0.7169)\end{array}$ \\
\hline R_score & & $\begin{array}{c}0.016 \\
(<.0001)\end{array}$ & $\begin{array}{c}0.113 \\
(<.0001)\end{array}$ & $\begin{array}{l}1.066 \\
(0.09)\end{array}$ \\
\hline Big_Auditor & & $\begin{array}{c}-0.002 \\
(0.3261)\end{array}$ & $\begin{array}{c}0.000 \\
(0.9752)\end{array}$ & $\begin{array}{c}0.471 \\
(0.5181)\end{array}$ \\
\hline $\log (G$-score) & & $\begin{array}{c}-0.001 \\
(0.1243)\end{array}$ & $\begin{array}{c}0.005 \\
(0.0709)\end{array}$ & $\begin{array}{c}0.959 \\
(0.0037)\end{array}$ \\
\hline Inst_Holding & & $\begin{array}{c}0.003 \\
(0.1231)\end{array}$ & $\begin{array}{l}-0.010 \\
(0.134)\end{array}$ & $\begin{array}{c}0.840 \\
(0.2043)\end{array}$ \\
\hline Regulation & & $\begin{array}{c}0.000 \\
(0.6602)\end{array}$ & $\begin{array}{c}-0.012 \\
(0.0016)\end{array}$ & $\begin{array}{c}0.712 \\
(0.0275)\end{array}$ \\
\hline Litigation & & $\begin{array}{c}0.002 \\
(0.0003)\end{array}$ & $\begin{array}{c}0.015 \\
(<.0001)\end{array}$ & $\begin{array}{c}0.613 \\
(0.0021)\end{array}$ \\
\hline CEO_Chair & & $\begin{array}{c}-0.001 \\
(0.2138)\end{array}$ & $\begin{array}{c}-0.002 \\
(0.2146)\end{array}$ & $\begin{array}{c}-0.139 \\
(0.4367)\end{array}$ \\
\hline Board_Size & & $\begin{array}{c}0.000 \\
(0.0037)\end{array}$ & $\begin{array}{c}-0.001 \\
(0.0565)\end{array}$ & $\begin{array}{l}-0.019 \\
(0.648)\end{array}$ \\
\hline Board_Indep & & $\begin{array}{c}0.000 \\
(0.0717)\end{array}$ & $\begin{array}{c}0.000 \\
(0.0995)\end{array}$ & $\begin{array}{c}0.005 \\
(0.3077)\end{array}$ \\
\hline Intercept & & $\begin{array}{c}0.006 \\
(0.076)\end{array}$ & $\begin{array}{c}0.064 \\
(<.0001)\end{array}$ & $\begin{array}{l}-10.087 \\
(<.0001)\end{array}$ \\
\hline $\begin{array}{l}\text { Adjusted } R^{2} \\
\# \text { of Obs }\end{array}$ & & $\begin{array}{c}39.75 \% \\
5,023 \\
\end{array}$ & $\begin{array}{c}32.18 \% \\
4,838 \\
\end{array}$ & $\begin{array}{l}6.1 \%^{+} \\
5,399\end{array}$ \\
\hline
\end{tabular}

Notes: $p$-values are in parentheses, and are one-tailed if there is a directional prediction; two-tailed otherwise; + Max-rescaled $\mathrm{R}^{2}$; all the variable definitions are included in Appendix A; 
Table 6: Regression results using an alternative way to measure board interlocks

\begin{tabular}{|c|c|c|c|c|}
\hline & & (1) & (2) & (3) \\
\hline Variables & Pred. & $\mathrm{AQ}$ & $|\overline{D A}|$ & Restate_0/1 \\
\hline Log(\#Restate_link 01) & + & $\begin{array}{c}0.002 \\
(0.001)\end{array}$ & $\begin{array}{c}0.011 \\
(<.0001)\end{array}$ & $\begin{array}{c}0.790 \\
(<.0001)\end{array}$ \\
\hline Log(\#Board_links01) & - & $\begin{array}{c}-0.000 \\
(0.1579)\end{array}$ & $\begin{array}{c}-0.004 \\
(0.0041)\end{array}$ & $\begin{array}{c}-0.399 \\
(0.0029)\end{array}$ \\
\hline$R O A$ & & $\begin{array}{c}-0.010 \\
(0.0062)\end{array}$ & $\begin{array}{c}-0.039 \\
(0.0014)\end{array}$ & $\begin{array}{c}-0.451 \\
(0.6496)\end{array}$ \\
\hline \#Loss & & $\begin{array}{c}0.001 \\
(0.2589)\end{array}$ & $\begin{array}{c}0.008 \\
(0.0038)\end{array}$ & $\begin{array}{c}0.218 \\
(0.3933)\end{array}$ \\
\hline Log(Operating_Cycle) & & $\begin{array}{c}0.007 \\
(<.0001)\end{array}$ & $\begin{array}{c}-0.009 \\
(<.0001)\end{array}$ & $\begin{array}{c}0.241 \\
(0.0848)\end{array}$ \\
\hline $\log (T A)$ & & $\begin{array}{c}-0.008 \\
(<.0001)\end{array}$ & $\begin{array}{c}0.002 \\
(0.1155)\end{array}$ & $\begin{array}{c}0.033 \\
(0.8245)\end{array}$ \\
\hline $\log (S A L E S)$ & & $\begin{array}{c}0.006 \\
(<.0001)\end{array}$ & $\begin{array}{c}-0.004 \\
(0.0093)\end{array}$ & $\begin{array}{c}0.182 \\
(0.244)\end{array}$ \\
\hline$M B$ & & $\begin{array}{c}0.000 \\
(0.0928)\end{array}$ & $\begin{array}{c}0.002 \\
(<.0001)\end{array}$ & $\begin{array}{c}-0.053 \\
(0.0822)\end{array}$ \\
\hline Leverage & & $\begin{array}{c}0.003 \\
(0.0491)\end{array}$ & $\begin{array}{c}-0.030 \\
(<.0001)\end{array}$ & $\begin{array}{c}0.698 \\
(0.1394)\end{array}$ \\
\hline$\sigma \_C F O$ & & $\begin{array}{c}0.158 \\
(<.0001)\end{array}$ & $\begin{array}{c}0.340 \\
(<.0001)\end{array}$ & $\begin{array}{c}1.839 \\
(0.3532)\end{array}$ \\
\hline$\sigma \_R E V$ & & $\begin{array}{c}0.012 \\
(<.0001)\end{array}$ & $\begin{array}{c}0.002 \\
(0.6062)\end{array}$ & $\begin{array}{c}0.157 \\
(0.6923)\end{array}$ \\
\hline R_score & & $\begin{array}{c}0.016 \\
(<.0001)\end{array}$ & $\begin{array}{c}0.114 \\
(<.0001)\end{array}$ & $\begin{array}{c}1.092 \\
(0.0832)\end{array}$ \\
\hline Big_Auditor & & $\begin{array}{c}-0.001 \\
(0.3552)\end{array}$ & $\begin{array}{c}0.000 \\
(0.9917)\end{array}$ & $\begin{array}{c}0.475 \\
(0.5144)\end{array}$ \\
\hline $\log (G$-score) & & $\begin{array}{c}-0.001 \\
(0.1275)\end{array}$ & $\begin{array}{c}0.005 \\
(0.078)\end{array}$ & $\begin{array}{c}0.954 \\
(0.004)\end{array}$ \\
\hline Inst_Holding & & $\begin{array}{c}0.003 \\
(0.1528)\end{array}$ & $\begin{array}{c}-0.011 \\
(0.0917)\end{array}$ & $\begin{array}{c}0.698 \\
(0.2945)\end{array}$ \\
\hline Regulation & & $\begin{array}{c}0.000 \\
(0.6689)\end{array}$ & $\begin{array}{c}-0.012 \\
(0.0025)\end{array}$ & $\begin{array}{c}0.695 \\
(0.0316)\end{array}$ \\
\hline Litigation & & $\begin{array}{c}0.002 \\
(0.0006)\end{array}$ & $\begin{array}{c}0.015 \\
(<.0001)\end{array}$ & $\begin{array}{c}0.576 \\
(0.0038)\end{array}$ \\
\hline CEO_Chair & & $\begin{array}{c}-0.001 \\
(0.2486)\end{array}$ & $\begin{array}{c}-0.002 \\
(0.2581)\end{array}$ & $\begin{array}{c}-0.128 \\
(0.4745)\end{array}$ \\
\hline Board_Size & & $\begin{array}{c}0.000 \\
(0.0033)\end{array}$ & $\begin{array}{c}-0.001 \\
(0.0361)\end{array}$ & $\begin{array}{l}-0.031 \\
(0.471)\end{array}$ \\
\hline Board_Indep & & $\begin{array}{c}0.000 \\
(0.0653)\end{array}$ & $\begin{array}{c}0.000 \\
(0.1799)\end{array}$ & $\begin{array}{c}0.004 \\
(0.3931)\end{array}$ \\
\hline Intercept & & $\begin{array}{c}0.007 \\
(0.0628)\end{array}$ & $\begin{array}{c}0.068 \\
(<.0001)\end{array}$ & $\begin{array}{c}-9.674 \\
(<.0001)\end{array}$ \\
\hline $\begin{array}{l}\text { Adjusted } R^{2} \\
\# \text { of Obs }\end{array}$ & & $\begin{array}{c}39.79 \% \\
5,023\end{array}$ & $\begin{array}{c}32.41 \% \\
4,838 \\
\end{array}$ & $\begin{array}{c}6.48 \%^{+} \\
5,399 \\
\end{array}$ \\
\hline
\end{tabular}

Notes: $p$-values are in parentheses, and are one-tailed if there is a directional prediction; two-tailed otherwise; + Max-rescaled $\mathrm{R}^{2}$; all the variable definitions are included in Appendix A; 
Table 7 : Regression Results considering Insiders

\begin{tabular}{|c|c|c|c|c|}
\hline & & (1) & $(2)$ & (3) \\
\hline Variables & Pred. & $\mathrm{AQ}$ & $|\overline{D A}|$ & Restate_0/1 \\
\hline Log(\#Restate_Insider_link) & + & $\begin{array}{c}0.004 \\
(0.0081)\end{array}$ & $\begin{array}{c}0.006 \\
(0.1165)\end{array}$ & $\begin{array}{c}0.710 \\
(0.0423)\end{array}$ \\
\hline Log(\#Restate_link) & + & $\begin{array}{c}0.001 \\
(0.0205)\end{array}$ & $\begin{array}{c}0.009 \\
(<.0001)\end{array}$ & $\begin{array}{c}0.683 \\
(0.0006)\end{array}$ \\
\hline Log(\#Board_link) & - & $\begin{array}{c}-0.001 \\
(0.0466)\end{array}$ & $\begin{array}{c}-0.006 \\
(0.0001)\end{array}$ & $\begin{array}{c}-0.528 \\
(0.0012)\end{array}$ \\
\hline$R O A$ & & $\begin{array}{c}-0.011 \\
(0.0035)\end{array}$ & $\begin{array}{c}-0.039 \\
(0.0021)\end{array}$ & $\begin{array}{c}0.279 \\
(0.796)\end{array}$ \\
\hline \#Loss & & $\begin{array}{c}0.001 \\
(0.1493)\end{array}$ & $\begin{array}{c}0.009 \\
(0.0015)\end{array}$ & $\begin{array}{c}0.318 \\
(0.2395)\end{array}$ \\
\hline $\log (T A)$ & & $\begin{array}{c}-0.008 \\
(<.0001)\end{array}$ & $\begin{array}{c}0.004 \\
(0.0152)\end{array}$ & $\begin{array}{c}0.061 \\
(0.6923)\end{array}$ \\
\hline $\log (S A L E S)$ & & $\begin{array}{c}0.006 \\
(<.0001)\end{array}$ & $\begin{array}{c}-0.005 \\
(0.0018)\end{array}$ & $\begin{array}{c}0.183 \\
(0.2616)\end{array}$ \\
\hline$M B$ & & $\begin{array}{c}0.000 \\
(0.5128)\end{array}$ & $\begin{array}{c}0.001 \\
(<.0001)\end{array}$ & $\begin{array}{c}-0.056 \\
(0.0744)\end{array}$ \\
\hline Leverage & & $\begin{array}{c}0.004 \\
(0.0065)\end{array}$ & $\begin{array}{c}-0.029 \\
(<.0001)\end{array}$ & $\begin{array}{c}0.966 \\
(0.0522)\end{array}$ \\
\hline Log(Operating_Cycle) & & $\begin{array}{c}0.007 \\
(<.0001)\end{array}$ & $\begin{array}{c}-0.010 \\
(<.0001)\end{array}$ & $\begin{array}{c}0.191 \\
(0.1986)\end{array}$ \\
\hline$\sigma \_C F O$ & & $\begin{array}{c}0.157 \\
(<.0001)\end{array}$ & $\begin{array}{c}0.365 \\
(<.0001)\end{array}$ & $\begin{array}{c}1.700 \\
(0.4183)\end{array}$ \\
\hline$\sigma \_R E V$ & & $\begin{array}{c}0.011 \\
(<.0001)\end{array}$ & $\begin{array}{c}0.000 \\
(0.9946)\end{array}$ & $\begin{array}{c}0.195 \\
(0.6371)\end{array}$ \\
\hline R_score & & $\begin{array}{c}0.019 \\
(<.0001)\end{array}$ & $\begin{array}{c}0.114 \\
(<.0001)\end{array}$ & $\begin{array}{c}1.325 \\
(0.0467)\end{array}$ \\
\hline Big_Auditor & & $\begin{array}{c}0.004 \\
(0.0583)\end{array}$ & $\begin{array}{c}0.000 \\
(0.9774)\end{array}$ & $\begin{array}{c}0.690 \\
(0.4983)\end{array}$ \\
\hline $\log (G$-score) & & $\begin{array}{c}-0.002 \\
(0.0256)\end{array}$ & $\begin{array}{c}0.005 \\
(0.1102)\end{array}$ & $\begin{array}{c}0.873 \\
(0.0136)\end{array}$ \\
\hline Inst_Holding & & $\begin{array}{c}0.002 \\
(0.2885)\end{array}$ & $\begin{array}{l}-0.012 \\
(0.079)\end{array}$ & $\begin{array}{c}0.746 \\
(0.2983)\end{array}$ \\
\hline Regulation & & $\begin{array}{c}-0.001 \\
(0.4008)\end{array}$ & $\begin{array}{c}-0.015 \\
(0.0001)\end{array}$ & $\begin{array}{c}0.481 \\
(0.1796)\end{array}$ \\
\hline Litigation & & $\begin{array}{c}0.002 \\
(0.0084)\end{array}$ & $\begin{array}{c}0.014 \\
(<.0001)\end{array}$ & $\begin{array}{c}0.640 \\
(0.0024)\end{array}$ \\
\hline CEO_Chair & & $\begin{array}{c}-0.001 \\
(0.1302)\end{array}$ & $\begin{array}{c}-0.001 \\
(0.4103)\end{array}$ & $\begin{array}{c}-0.057 \\
(0.7673)\end{array}$ \\
\hline Board_Size & & $\begin{array}{c}0.000 \\
(0.0612)\end{array}$ & $\begin{array}{c}0.000 \\
(0.3582)\end{array}$ & $\begin{array}{c}-0.027 \\
(0.5492)\end{array}$ \\
\hline Board_Indep & & $\begin{array}{c}0.000 \\
(0.5861)\end{array}$ & $\begin{array}{c}0.000 \\
(0.4233)\end{array}$ & $\begin{array}{c}0.006 \\
(0.2736)\end{array}$ \\
\hline Intercept & & $\begin{array}{c}0.004 \\
(0.3192)\end{array}$ & $\begin{array}{c}0.071 \\
(<.0001)\end{array}$ & $\begin{array}{c}-9.916 \\
(<.0001)\end{array}$ \\
\hline $\begin{array}{l}\text { Adjusted } R^{2} \\
\# \text { of Obs }\end{array}$ & & $\begin{array}{c}40.50 \% \\
4,485\end{array}$ & $\begin{array}{c}34.39 \% \\
4,296\end{array}$ & $\begin{array}{c}7.65 \%^{+} \\
4,806\end{array}$ \\
\hline
\end{tabular}

Notes: $\mathrm{p}$-values are in parentheses, and are one-tailed if there is a directional prediction; two-tailed otherwise; + Max-rescaled $\mathrm{R}^{2}$; all the variable definitions are included in Appendix A; 
Table 8: Regression Results considering tainted directors' industries

\begin{tabular}{|c|c|c|c|c|}
\hline & & (1) & $(2)$ & (3) \\
\hline Variables & Pred. & $\mathrm{AQ}$ & $|\overline{D A}|$ & Restate $0 / 1$ \\
\hline Log(\#Restate_link_same_ind) & + & $\begin{array}{c}0.008 \\
(<.0001)\end{array}$ & $\begin{array}{c}0.052 \\
(<.0001)\end{array}$ & $\begin{array}{c}0.099 \\
(0.4265)\end{array}$ \\
\hline Log(\#Restate_link_diff_ind) & + & $\begin{array}{c}0.001 \\
(0.0221)\end{array}$ & $\begin{array}{c}0.006 \\
(0.0028)\end{array}$ & $\begin{array}{c}0.785 \\
(0.0001)\end{array}$ \\
\hline Log(\#Board_link) & - & $\begin{array}{c}-0.001 \\
(0.0339)\end{array}$ & $\begin{array}{c}-0.005 \\
(0.0004)\end{array}$ & $\begin{array}{c}-0.443 \\
(0.0055)\end{array}$ \\
\hline$R O A$ & & $\begin{array}{c}-0.011 \\
(0.0041)\end{array}$ & $\begin{array}{c}-0.035 \\
(0.0054)\end{array}$ & $\begin{array}{c}0.330 \\
(0.7589)\end{array}$ \\
\hline \#Loss & & $\begin{array}{c}0.001 \\
(0.2083)\end{array}$ & $\begin{array}{c}0.008 \\
(0.0045)\end{array}$ & $\begin{array}{c}0.333 \\
(0.2195)\end{array}$ \\
\hline $\log (T A)$ & & $\begin{array}{c}-0.008 \\
(<.0001)\end{array}$ & $\begin{array}{c}0.004 \\
(0.0091)\end{array}$ & $\begin{array}{c}0.092 \\
(0.5504)\end{array}$ \\
\hline $\log (S A L E S)$ & & $\begin{array}{c}0.006 \\
(<.0001)\end{array}$ & $\begin{array}{c}-0.006 \\
(0.0006)\end{array}$ & $\begin{array}{c}0.158 \\
(0.3378)\end{array}$ \\
\hline$M B$ & & $\begin{array}{c}0.000 \\
(0.5868)\end{array}$ & $\begin{array}{c}0.001 \\
(<.0001)\end{array}$ & $\begin{array}{c}-0.058 \\
(0.0617)\end{array}$ \\
\hline Leverage & & $\begin{array}{c}0.004 \\
(0.0048)\end{array}$ & $\begin{array}{c}-0.026 \\
(<.0001)\end{array}$ & $\begin{array}{c}1.015 \\
(0.0423)\end{array}$ \\
\hline Log(Operating_Cycle) & & $\begin{array}{c}0.007 \\
(<.0001)\end{array}$ & $\begin{array}{c}-0.010 \\
(<.0001)\end{array}$ & $\begin{array}{c}0.163 \\
(0.2802)\end{array}$ \\
\hline$\sigma_{-} C F O$ & & $\begin{array}{c}0.156 \\
(<.0001)\end{array}$ & $\begin{array}{c}0.365 \\
(<.0001)\end{array}$ & $\begin{array}{c}1.586 \\
(0.4537)\end{array}$ \\
\hline$\sigma_{-} R E V$ & & $\begin{array}{c}0.011 \\
(<.0001)\end{array}$ & $\begin{array}{c}-0.001 \\
(0.8105)\end{array}$ & $\begin{array}{c}0.177 \\
(0.6721)\end{array}$ \\
\hline$R \_s c o r e$ & & $\begin{array}{c}0.019 \\
(<.0001)\end{array}$ & $\begin{array}{c}0.112 \\
(<.0001)\end{array}$ & $\begin{array}{c}1.483 \\
(0.025)\end{array}$ \\
\hline Big_Auditor & & $\begin{array}{c}0.004 \\
(0.0564)\end{array}$ & $\begin{array}{c}-0.001 \\
(0.8592)\end{array}$ & $\begin{array}{c}0.678 \\
(0.5061)\end{array}$ \\
\hline $\log (G$-score $)$ & & $\begin{array}{c}-0.002 \\
(0.0163)\end{array}$ & $\begin{array}{c}0.003 \\
(0.2803)\end{array}$ & $\begin{array}{c}0.877 \\
(0.014)\end{array}$ \\
\hline Inst_Holding & & $\begin{array}{c}0.002 \\
(0.3725)\end{array}$ & $\begin{array}{c}-0.012 \\
(0.068)\end{array}$ & $\begin{array}{c}0.831 \\
(0.2467)\end{array}$ \\
\hline Regulation & & $\begin{array}{c}-0.001 \\
(0.2832)\end{array}$ & $\begin{array}{c}-0.017 \\
(<.0001)\end{array}$ & $\begin{array}{c}0.333 \\
(0.3749)\end{array}$ \\
\hline Litigation & & $\begin{array}{c}0.001 \\
(0.0239)\end{array}$ & $\begin{array}{c}0.014 \\
(<.0001)\end{array}$ & $\begin{array}{c}0.671 \\
(0.0015)\end{array}$ \\
\hline CEO_Chair & & $\begin{array}{c}-0.001 \\
(0.0772)\end{array}$ & $\begin{array}{c}-0.001 \\
(0.6138)\end{array}$ & $\begin{array}{c}-0.052 \\
(0.7908)\end{array}$ \\
\hline Board_Size & & $\begin{array}{c}0.000 \\
(0.0624)\end{array}$ & $\begin{array}{c}0.000 \\
(0.6775)\end{array}$ & $\begin{array}{c}-0.043 \\
(0.3603)\end{array}$ \\
\hline Board_Indep & & $\begin{array}{c}0.000 \\
(0.5384)\end{array}$ & $\begin{array}{c}0.000 \\
(0.3871)\end{array}$ & $\begin{array}{c}0.004 \\
(0.4232)\end{array}$ \\
\hline Intercept & & $\begin{array}{c}0.005 \\
(0.2228)\end{array}$ & $\begin{array}{c}0.072 \\
(<.0001)\end{array}$ & $\begin{array}{c}-9.779 \\
(<.0001)\end{array}$ \\
\hline $\begin{array}{l}\text { Adjusted } R^{2} \\
\# \text { of Obs }\end{array}$ & & $\begin{array}{c}40.52 \% \\
4,395\end{array}$ & $\begin{array}{c}35.68 \% \\
4,207\end{array}$ & $\begin{array}{c}7.23 \%^{+} \\
4,709\end{array}$ \\
\hline
\end{tabular}

Notes: $p$-values are in parentheses, and are one-tailed if there is a directional prediction; two-tailed otherwise; + Max-rescaled $\mathrm{R}^{2}$; all the variable definitions are included in Appendix A; 